
6

\title{
Black carbon radiative forcing derived from AERONET measurements and models over an urban location in the southeastern Iberian Peninsula
}

\author{
Valenzuela, A. ${ }^{1,2,3}$, Arola, A. ${ }^{4}$ Antón, M. ${ }^{5}$, Quirantes, A. ${ }^{2}$ Alados-Arboledas, \\ L. ${ }^{2,3}$ \\ ${ }^{1}$ Departamento de Física, Instituto de Ciências da Terra, Instituto de Investigação e \\ Formação Avançada, Universidade de Évora, Évora (Portugal) \\ ${ }^{2}$ Departamento de Física Aplicada, Universidad de Granada, Granada, Spain \\ ${ }^{3}$ Andalusian Institute for Earth System Research (IISTA-CEAMA), Granada, Spain \\ ${ }^{4}$ Finnish Meteorological Institute (FMI), Kuopio, Finland \\ ${ }^{5}$ Departamento de Física, Universidad de Extremadura, Badajoz, Spain
}

Keywords: aerosol particles, anthropogenic aerosol, black carbon, shortwave radiative forcing.

\section{Abstract}

This paper provides an account of observed variations in Black carbon (BC) aerosol concentrations and their induced radiative forcing for the first time over Granada a measurement site in Southeastern Iberian Peninsula. Column-integrated BC concentrations were retrieved for the period 2005-2012. Monthly averages of BC concentrations $( \pm$ one standard deviation) ranged from higher values in January and December with $4.0 \pm 2.5$ and $4 \pm 3 \mathrm{mg} / \mathrm{m}^{2}$, respectively, to lower values in July and August with $1.6 \pm 1.2$ and 
$252.0 \pm 0.5 \mathrm{mg} / \mathrm{m}^{2}$, respectively. This reduction is not only observed in the average values, but 26 also in the median, third and first quartiles. The average BC concentration in winter

$27\left(3.8 \pm 0.6 \mathrm{mg} / \mathrm{m}^{2}\right)$ was substantially higher than in summer $\left(1.9 \pm 0.3 \mathrm{mg} / \mathrm{m}^{2}\right)$, being the eight28 year average of $2.9 \pm 0.9 \mathrm{mg} / \mathrm{m}^{2}$. The reduction in the use of fossil fuels during the economic 29 crisis contributed significantly to reduced atmospheric loadings of BC. According to our 30 analysis this situation persisted until 2010. BC concentration values were analyzed in terms 31 of air mass influence using cluster analysis. BC concentrations for cluster 1 (local and 32 regional areas) showed high correlations with air masses frequency in winter and autumn. 33 In these seasons $\mathrm{BC}$ sources were related to the intense road traffic and increased $\mathrm{BC}$ 34 emissions from domestic heating. High BC concentrations were found in autumn just when 35 air mass frequencies for cluster 3 (Mediterranean region) were more elevated, suggesting that air masses coming from that area transport biomass burning particles towards Granada.

37 BC aerosol optical properties were retrieved from BC fraction using aerosol AERONET 38 size volume distribution and Mie theory. A radiative transfer model (SBDART) was used 39 to estimate the aerosol radiative forcing separately for composite aerosol (total aerosols) 40 and exclusively for $\mathrm{BC}$ aerosols. The mean radiative forcing for composite aerosol was $41+23 \pm 6 \mathrm{~W} / \mathrm{m}^{2}$ (heating rate of $+0.21 \pm 0.06 \mathrm{~K} /$ day) and $+15 \pm 6 \mathrm{~W} / \mathrm{m}^{2}$ for $\mathrm{BC}$ aerosol (heating 42 rate of $+0.15 \pm 0.06 \mathrm{~K} /$ day). These values of radiative forcing and heating rate for $\mathrm{BC}$ 43 aerosol represent about $70 \%$ of their values for composite aerosol, which highlights the 44 crucial role that $\mathrm{BC}$ aerosols play in modifying the radiation budget and climate. 


\section{$47 \quad$ 1. Introduction}

48 Black carbon (BC) is the dominant absorbing aerosol in the solar radiation spectrum,

49 playing a key role in the estimation of the direct radiative forcing although it accounts for

50 less than $5 \%$ of the mass of atmospheric aerosol in most areas of the world (Haywood and

51 Since, 1997; Zhang et al., 2012). Bond et al. (2013) provided an inventory of the major BC

52 sources. They are listed according to the importance of emission: The bottom-up estimates

53 predicts that open burning contributes about $40 \%$ of total BC emissions. Residential Solid

54 Fuels (Wood, agricultural waste, dung, and coal) provide another $25 \%$ of BC emissions.

55 The diesel-engine category (on-road and off-road engines) is estimated that contributed

56 about $20 \%$ of global BC emissions of the total. Finally, industrial coal combustion is

57 estimated to provide about $9 \%$ of global emissions. BC is directly emitted into the air from

58 these sources, not formed in the atmosphere from precursor substances. Estimates of BC

59 global annual emissions were 8.0 $\mathrm{Tg}$. The uncertainties were about a factor of 2, with

60 uncertainty range of 4.3-22 Tg/yr. BC particles are generally produced from the incomplete

61 combustion of fossil fuels and biomass burning (Zhao et al., 2015). BC can raise the

62 amount of solar radiation absorbed in the visible and infrared spectral ranges within the

63 Earth's climate system and, consequently, heat the atmosphere and surface (Hansen et al.,

64 2000; Ramanathan and Carmichael, 2008). Ramanathan and Carmichael (2008) performed

65 a comparison of radiative forcing caused by greenhouse gases and $\mathrm{BC}$. They found that the

66 direct radiative forcing due to $\mathrm{BC}$ was larger than that due to any other greenhouse gas

67 except $\mathrm{CO}_{2}$. $\mathrm{BC}$ causes large atmospheric warming constituting about $55 \%$ of $\mathrm{CO}_{2}$ forcing

68 on the global scale (Ramanathan and Carmichael, 2008; Keil et al., 2001; Babu et al., 2002;

69 Bond et al., 2013). Bond et al. (2013) estimated a climate forcing due to BC of $+1.1 \mathrm{~W} / \mathrm{m}^{2}$ 
70 with $90 \%$ uncertainty limits of +0.17 to $+2.1 \mathrm{~W} / \mathrm{m}^{2}$. The process through which $\mathrm{BC}$ 71 suspended in the atmosphere scatters and absorbs incoming solar radiation is termed " 72 direct effect', The absorption by BC suspended warms the air, but the extinction of 73 radiation results a negative forcing at the Earth's surface (Ramanathan and Carmichael, 74 2008). The "semi-direct effect'" assumes that BC particles reside interstitially between 75 cloud droplets (Johnson, 2004; Chung and Seinfeld, 2005; Jacobson, 2006; Jones et al., 76 2007). BC also has significant effects on clouds by changing atmospheric stability, 77 affecting cloud formation (Ackerman et al., 2000). Therefore, BC is considered as a 78 potential cause of global warming (Hansen et al., 2000; Bond et al., 2013). BC may also 79 play a relevant role for the aerosol cloud ("indirect effect") since it is injected into the 80 atmosphere as primary aerosol particle, affecting the number of particles available in cloud 81 condensation (Oshima et al., 2009).

82 There are a large number of papers focused on the analysis of aerosol measurements over 83 the Iberian Peninsula (e.g., Silva et al., 2002; Olmo et al., 2006; Estellés et al., 2007; 84 Cachorro et al., 2008; Prats et al., 2008; Toledano et al., 2009; Pereira et al., 2011; 85 Valenzuela 2012a). However, none of them were focused on studying the BC aerosol in 86 this region. To our knowledge, only Lyamani et al. (2011) performed a detailed analysis 87 about BC concentration at the surface level. They measured significant amount of BC over 88 surface in Granada with mean value of $3.0 \pm 1.5 \mu \mathrm{g} / \mathrm{m}^{3}$. These authors also reported that BC 89 exhibited a well-defined seasonal variation with the highest concentration during winter 90 likely due to increased emissions from domestic heating and a lower planetary layer height 91 (Granados et al., 2012). The disadvantage of in situ measurements is that require 92 considerable effort and this technique does not provide large spatial and temporal coverage 
93 (Derimian et al., 2008). Recently, some studies have paid attention to retrieve aerosol 94 composition from AERONET retrievals, since it provides worthy information on aerosol 95 optical and physical properties such as column-averaged aerosol refractive indices and size 96 distributions (Schuster et al., 2005; Dey et al., 2006; Arola et al., 2011). They derived 97 information of $\mathrm{BC}$ concentration from AERONET imaginary refractive indices assumes 98 that absorption is due to three components: Black Carbon (BC), Brown Carbon (BrC) and mineral dust (MD). In addition, it can also provide a long term view and extensive spatial coverage, as it comprises more than 300 sun photometers placed throughout the world 101 (Holben et al., 1998).

Long-range transport of $\mathrm{BC}$ has a great significance on the climate change and air quality.

103 However, large uncertainties remain between simulated and observed global transport of 104 BC. Uncertainties in models result from many factors, including BC emissions inventories, 105 the parameterizations of BC aging, wet removal, and dry deposition processes (Liu et al., 106 2011; Shen et al., 2014). BC aging process occurring during long-range transport is a key 107 factor in simulated concentrations of BC. The aging process refers to a transformation from 108 hydrophobic to hydrophilic aerosols, where aged BC particles can act as CCN and, thus, 109 they can be removed by wet scavenging when BC is trapped in cloud droplets or ice 110 crystals. From all pathways for the hydrophobic-to-hydrophilic conversion, chemical aging 111 is the least understood, but potentially could affect hydrophobic-to-hydrophilic conversion 112 on time scales shorter than days or weeks (Kanakidou et al., 2005). Therefore, the rate of 113 aging significantly affects the atmospheric lifetime of $\mathrm{BC}$, being one of the key factors 114 controlling long-range transport of these particles and, consequently, affecting their global 
115 distribution (Liu et al., 2011). However, the aging of BC is highly simplified in global 116 models and, thus, errors related to the $\mathrm{BC}$ wet scavenging should be taken into account.

117 Backward trajectory analysis is a well-known technique to link air mass-origin with aerosol 118 optical properties at the measurements area (e.g. Kokkalis et al., 2017; Kumar et al., 2017; 119 Zdun et al., 2016; Valenzuela et al., 2015). The analysis of backward trajectories provides 120 objective interpretations related to source regions, residence times over each region and 121 different circulation patterns (curvature and length) of air masses. The accuracy of back122 trajectories showed position errors with the travel's distance (Stohl, 1998). These errors 123 produce divergence in the back-trajectories and they are associated with five causes (Harris 124 et al., 2005): differences in computational methodology, 3-4\%; time interpolation, 9-25\%; 125 vertical movement method, 18-34\%; meteorological input data, 30-40\%; and combined 126 two-way differences in vertical transport method and meteorological input data, 39-47\%. 127 This sensitivity test was performed for 96 hours of flight time. In other studies, seven-day 128 back trajectory calculations were done taking into account the aerosols residence time of 129 around one week in the lower atmosphere in the northern midlatitudes (Kumar Bharath, $\mathrm{d}$. 130 and S. Verma, 2016).

131 Some studies have focused on the characterization of the aerosol radiative forcing during 132 desert dust events over southeastern Iberian Peninsula (e.g., Anton, et al., 2012; Valenzuela 133 et al., 2012b). However, to our knowledge, no study has addressed the characterization of 134 the $\mathrm{BC}$ content in the entire atmospheric column and their radiative effects over the 135 southeastern Iberian Peninsula. Hence, it is a challenge to carry out the first study of BC 136 content retrieved from sun-photometer measurements over southeastern Iberian Peninsula, 
137

138

139

140

141

142

143

144

145

146

147

148

149

150

151

152

153

154

155

156

157

158

especially considering that is has relevance not only from the local point of view, but also from a regional perspective. Thus we develop a detailed analysis of $\mathrm{BC}$ aerosol in Granada urban atmosphere for the period 2005-2012. Furthermore, the BC radiative effects in the shortwave spectral range will be determined and, compared with the radiative effects of the total aerosol (composite aerosol), although restricted to fine mode-dominated cases.

\section{Experimental site, instrumentation and data}

Ground-based data were retrieved at the radiometric station located on the rooftop of the Andalusian Institute for Earth System Research (IISTA-CEAMA, 37.168N, 3.608W) in

Granada (South-Eastern Spain) which is found at $680 \mathrm{~m}$ a.s.l. (Figure 1). Granada is a medium-sized city with little emissions associated with large-scale industrial activities and with a population of 300,000 inhabitants. However anthropogenic fine aerosols load are expected from domestic heating and intense road traffic in the city and metropolitan area (Lyamani et al., 2011). The city is found in a natural basin close to Sierra Nevada's mountain range to the southeastern with elevations between 1000 and $3500 \mathrm{~m}$ a.s.1. The is frequently affected by air masses coming from the Atlantic Ocean, the European and African continents, and less frequently from the Mediterranean Sea (Lyamani et al., 2010).

Total columnar aerosol properties were retrieved from measurements of CIMEL CE-318 sun-photometer which is included in the AERONET network (Holben et al., 1998). This instrument makes direct sun measurements with a $1.2^{\circ}$ full field of view at $340,380,440$, $500,675,870$ and $1020 \mathrm{~nm}$. The full-width at half-maximum of the interference filters are 2 $\mathrm{nm}$ at $340 \mathrm{~nm}, 4 \mathrm{~nm}$ at $380 \mathrm{~nm}$ and $10 \mathrm{~nm}$ at all other wavelengths. The sky radiance measurements (almucantar configuration) are carried out at 440, 675, 870 and $1020 \mathrm{~nm}$. 
159 The characteristics of the CIMEL sun-photometer are fully described by Holben et al. 160 (1998). The direct sun measurements are used to compute the aerosol optical depth (AOD) 161 at 340, 380, 440, 670, 870 and $1020 \mathrm{~nm}$ (Holben et al., 1998). The uncertainty in the 162 retrieval of AOD under cloud free conditions is \pm 0.01 for wavelengths larger than $440 \mathrm{~nm}$ 163 and \pm 0.02 for shorter wavelengths (Eck et al., 1999). Sky radiance measurements together 164 with solar direct irradiance measurements are used to retrieve aerosol optical properties like 165 single scattering albedo, $\omega(\lambda)$, using the AERONET inversion algorithm developed by 166 Dubovik and King (2000) as improved by Dubovik et al. (2006). The uncertainty in the 167 retrieval of $\omega(\lambda)$ is \pm 0.03 for high aerosol load (AOD $(440 \mathrm{~nm})>0.4)$ and solar zenith 168 angle $>50^{\circ}$. For measurements with low aerosol load $(\operatorname{AOD}(440 \mathrm{~nm})<0.2)$, the retrieval 169 accuracy of $\omega(\lambda)$, drops down to 0.02-0.07 (Dubovik et al., 2000).

\section{Methodology}

\section{$171 \quad 3.1$ BC content}

172 The technique used by Arola et al. (2011) has been utilized in this work to retrieve 173 information about $\mathrm{BC}$ aerosol concentration. This method is based on the approach 174 employed previously by Schuster et al. (2005). Further information regarding the method 175 can be found in the mentioned works. Thus, AERONET measurements of refractive index

176 and the above mentioned approach were used to retrieve information about $\mathrm{BC}$ aerosol 177 fraction. For a mixture of $\mathrm{BC}, \mathrm{BrC}$ and Ammonium Sulfate $\left(\mathrm{NH}_{4}\right)_{2}\left(\mathrm{SO}_{4}\right)$ embedded in 178 water host the Maxwell-Garnett (MG) mixing rule was applied. Similar refractive index 179 values for all components as those suggested by Arola et al. (2011) were considered. In the 180 present work, it is assumed that $\mathrm{BrC}$ was responsible for absorption at the ultraviolet 
181 spectral range that cannot be explained by BC. Considering all the inclusions as spherical, 182 the effective dielectric constant for the mixture $\left(\varepsilon_{M G}\right)$ follows the equation given by 183 (Bohren and Huffman, 1998, p.217):

184

$$
\varepsilon_{M G}=\varepsilon_{m}\left[1+\frac{3\left(f_{1} \frac{\varepsilon_{1}-\varepsilon_{m}}{\varepsilon_{1}+2 \varepsilon_{m}}+f_{2} \frac{\varepsilon_{2}-\varepsilon_{m}}{\varepsilon_{2}+2 \varepsilon_{m}}+f_{3} \frac{\varepsilon_{3}-\varepsilon_{m}}{\varepsilon_{3}+2 \varepsilon_{m}}\right)}{1-\left(f_{1} \frac{\varepsilon_{1}-\varepsilon_{m}}{\varepsilon_{1}+2 \varepsilon_{m}}-f_{2} \frac{\varepsilon_{2}-\varepsilon_{m}}{\varepsilon_{2}+2 \varepsilon_{m}}-f_{3} \frac{\varepsilon_{3}-\varepsilon_{m}}{\varepsilon_{3}+2 \varepsilon_{m}}\right)}\right]
$$

185 where $\varepsilon_{\mathrm{m}}, \varepsilon_{1}, \varepsilon_{2}$ and $\varepsilon_{3}$ are the dielectric constant of the host matrix (water), $\mathrm{BC}$, 186 Ammonium Sulfate and $\mathrm{BrC}$ and $\mathrm{f}_{1}, \mathrm{f}_{2}$ and $\mathrm{f}_{3}$ are the corresponding volume fractions of $\mathrm{BC}$, 187 Ammonium Sulfate and BrC, respectively.

188 189 190 191

$$
k(\lambda)=\sqrt{\frac{\sqrt{\varepsilon_{r}^{2}+\varepsilon_{i}^{2}}-\varepsilon_{r}}{2}}
$$

$$
n(\lambda)=\sqrt{\frac{\sqrt{\varepsilon_{r}{ }^{2}+\varepsilon_{i}^{2}}+\varepsilon_{r}}{2}}
$$

194 where $\varepsilon_{\mathrm{r}}$ and $\varepsilon_{\mathrm{i}}$ are the real and imaginary parts of the mixture dielectric constant. 195 According to MG, first, $\mathrm{k}(\lambda)$ has been retrieved taking into account different combinations 196 of $f_{1}$ and $f_{3}$. The objective is to determine the appropriate volume fractions of $f_{1}$ and $f_{3}$. 
197 They were adjusted until the $\chi^{2}$ fit of the computed $\mathrm{k}(\lambda)$ of the mixture was minimized with 198 respect to the AERONET retrieved $\mathrm{k}(\lambda)$ values by:

$$
\chi^{2}=\sum_{i=1}^{4} \frac{\left(k_{i}^{r t v}-k_{i}^{c a l}\right)^{2}}{\left(k_{i}^{r t v}\right)^{2}}
$$

where $\mathrm{k}_{\mathrm{i}}^{\mathrm{rtv}}$ is the imaginary refractive index retrieved from sun photometer measurements

201 and $\mathrm{k}_{\mathrm{i}}^{\text {cal }}$ is the value obtained from MG mixing rule, $\mathrm{i}$ being the summation index over four 202 wavelengths $(440,675,870$ and $1020 \mathrm{~nm})$ of AERONET. Once the calculated $\mathrm{k}(\lambda)$ matches 203 to sun-photometer retrieved $\mathrm{k}(\lambda)$ within certain limit $\left(\chi^{2}\right.$ in the order of $\left.10^{-3}\right)$, the volume 204 fraction of Ammonium Sulfate $\left(f_{2}\right)$ is adjusted to minimize $\chi^{2}$ fit for $n(\lambda)$. The volume 205 fractions of all the components for which $\chi^{2}$ values for $\mathrm{k}(\lambda)$ and for $\mathrm{n}(\lambda)$ are the lowest, are 206 chosen as the best values to retrieve BC concentration. In our study, column-integrated BrC 207 concentration was found to vary in a wide range $2.5-12.5 \mathrm{mg} / \mathrm{m}^{2}$ for the entire period. A 208 value for BC density $\left(\rho_{B C}\right)$ of $1.8 \mathrm{~g} / \mathrm{cm}^{3}$ was assumed and the column-integrated aerosol 209 volume size distributions from AERONET were considered to retrieve BC concentration:

$$
B C=f_{1} \rho_{B C} \int \frac{d V}{d \ln r} d \ln r
$$

211 where $\mathrm{r}$ is the particle radius in microns and $\mathrm{V}$ is the particle volume concentration

$212\left(\mu \mathrm{m}^{3} / \mu \mathrm{m}^{2}\right)$. Dust dominated cases were excluded, and only those retrievals with ratio of 213 fine mode to total volume concentration larger than 0.5 were taken into consideration. 


\subsection{Air mass transport}

217 Source-receptor relationships between the measurement areas and the potential emission

218 sources are investigated with the use of the particle dispersion model HYSPLIT_4 model.

219 Five-day back-trajectories of air mass arriving to Granada at 500, 1500 and 3000 m a.g.l.

220 were computed using HYSPLIT_4 model including vertical wind (Draxler and Hess, 1998)

221 coincident with BC observation days. In our work, the back-trajectories were computed for

222120 hours of flight time as a compromise between accuracy and the need to reconstruct as

223 complete as possible the average life cycle of aerosol particles in the atmosphere. The

224 NCEP/NCAR reanalysis database was used as meteorological file input (NOAA

225 Operational Model Archive Distribution System server at NCEP). First, for each day, one

226 single trajectory at each altitude level was computed with endpoint in Granada at 12:00

227 UTC. Additionally, a visual inspection of the back trajectories was performed at all levels

228 with the goal of checking that air mass arriving to Granada never overpasses North Africa.

229 To get information about air flow patterns, a statistical methodology was applied to a

230 dataset of 265 back trajectories over Granada. This classification method was based on the

231 geometric distance between individual back trajectories, taking into account the speed and

232 direction of the back trajectories. The results are clusters-mean which grouping individual

233 back trajectories with similar behavior. Air masses affecting Granada from 2005 to 2012,

234 when BC concentration was available, were classified according to their transport pathways

235 using HYSPLIT clustering algorithm (http://www.arl.noaa.gov/). The back trajectory types

236 were considered in terms of the permanent synoptic situations. Large scale circulation

237 features were related to certain trajectory centroids. The cluster analysis does not assume 
238 the existence of BC sources and their geographic locations for clustering the back trajectory

239 types. The centroid represents the average of the trajectories included in that cluster.

240 HYSPLIT model hold a tool for clustering based on the variations in both the total variance

241 between clusters (TSV, Spatial Variance Total) and the variance between each component

242 of back trajectory (SPVAR, Spatial Variance) (Draxler et al., 2009). First, a set of 265

243 back-trajectories arriving over Granada was obtained. An initial number of back trajectories

244 were chosen and, after grouping process, the result was a single cluster as average back

245 trajectory of some of them. After that, two trajectories were grouped at each step which

246 created smaller increase of TSV and SPAVR. Large changes were indicative of the

247 conglomerating of large different trajectories into the same cluster. Accordingly, the best

248 representation in the number of groups is just before the large percentage of change in TSV.

249 Four groups for $500 \mathrm{~m}$ a.g.l. were chosen in order to a better explanation of the air mass

250 transport regimes during the study period after additional analysis for different cluster

251 numbers. Within each cluster, individual trajectories were averaged to produce a cluster-

252 mean trajectory. The flow patterns of air masses at 1500 and $3000 \mathrm{~m}$ a.g.l. were similar to

253 the flow patterns retrieved at $500 \mathrm{~m}$ a.g.l.

\section{$254 \quad 3.3$ Calculation of radiative effects}

255 Both, aerosol optical properties for composite aerosol and exclusively for BC aerosol were

256 independently used as input in Santa Barbara Discrete-ordinate Atmospheric Radiative

257 Transfer model (SBDART) (Ricchiazzi et al., 1998) to derive instantaneous net fluxes

258 (down-up) in the 310-2800 $\mathrm{nm}$ spectral range at the surface and the top of the atmosphere

259 (TOA). Radiative transfer code characterizes atmospheric aerosol radiative effects using the 
260 solar zenith angle, the spectral aerosol optical depth (AOD), the spectral single scattering

261 albedo $(\omega)$, and the spectral asymmetry parameter (g) as input values. Regarding the

262 vertical distribution of aerosol, the SBDART profile was used which takes into account the

263 aerosol-loaded atmosphere fitting an exponential-decay to the aerosol optical depth derived

264 by sun-photometer. Total ozone column derived from the Ozone Monitoring Instrument

265 (OMI) satellite and the surface spectral albedo provided by the AERONET algorithm,

266 based on dynamic spectral and spatial model estimation at four wavelengths: 440, 675, 870

267 and $1020 \mathrm{~nm}$ were used as input in the model. Surface albedo is a very decisive input for

268 calculating the aerosol radiative effect. It was linearly interpolated between the retrieved

269 wavelength values. The surface albedo value at $440 \mathrm{~nm}$ was extrapolated to the shorter

270 wavelengths as well, while the wavelengths larger than $1020 \mathrm{~nm}$ were linearly extrapolated.

271 Size distributions and BC fractions were used to calculate the aerosol optical properties for

272 the BC, which was based on the Mie theory. Likewise, both the "composite aerosol" and

273 the "BC aerosol" were described by their respective spectral AOD, $\omega$ and g, which were

274 finally used to estimate the radiative effects.

275 The instantaneous aerosol radiative forcing for composite aerosol (ARF) at the surface

276 (TOA) is obtained as:

$$
A R F=F-F^{0}
$$

278 where $\mathrm{F}$ and $\mathrm{F}^{0}$ denote the shortwave net fluxes at surface (TOA) simulated with aerosol

279 information related to composite aerosol and without aerosol information, respectively. 
280 Following an identical procedure, the instantaneous aerosol radiative forcing for BC aerosol

281 (BCRF) at the surface (TOA) is obtained as:

$$
B C R F=F_{B C}-F^{0}
$$

283 where $F_{B C}$ is now the shortwave net flux at surface (TOA) simulated with aerosol 284 information but related exclusively to BC aerosol.

285 Daily mean values of both ARF and BCRF at the surface (TOA) are derived from 286 integration of the instantaneous forcing values at surface (TOA) averaged 24 hours (Bush 287 and Valero, 2003; Valenzuela et al., 2012):

$$
A R F_{\text {daily }}=\int \frac{A R F d t}{24}
$$

$$
B C R F_{\text {daily }}=\int \frac{B C R F d t}{24}
$$

290 Heating rate was determined according to the finite difference estimates of the irradiance 291 divergence at each pair of levels (Liou, 2002);

$$
\frac{\partial T}{\partial t}=\frac{g}{C_{p}} \frac{\Delta F_{\text {Atmosferic }}}{\Delta p}
$$

293 where $\mathrm{T}$ is the temperature $(\mathrm{K}), \mathrm{t}$ is the time $(\mathrm{s}), \mathrm{g}$ is the gravitational acceleration $(9.8$ $\left.294 \mathrm{~m} / \mathrm{s}^{2}\right), \mathrm{C}_{\mathrm{p}}$ is the specific heat $(\sim 1004 \mathrm{~J} / \mathrm{kgK}), \mathrm{F}$ is the net all-wave flux $\left(\mathrm{W} / \mathrm{m}^{2}\right)$, and $\mathrm{p}$ is the 295 pressure $(\mathrm{Pa})$. The relative standard error in radiative forcing and heating rate reported here, 296 taking into account the aerosol input parameters, uncertainties in BC concentrations, and 297 flux estimates, is estimated to be $25 \%$. 


\section{Results and discussion}

\subsection{Temporal variation of $\mathrm{BC}$ content}

300 BC aerosol concentrations were retrieved from 734 sun-photometer observations 301 corresponding to 265 days from 2005 to 2012 over Granada. BC concentrations exhibited 302 clear seasonal pattern, evident in the monthly BC concentrations observed during the entire 303 period (Fig. 2). The monthly mean BC concentrations were high in winter (December to 304 February) and autumn (September to November) and low in summer (June to August) and 305 spring (March to May), with the highest concentrations in winter and the lowest in summer. 306 Vertical bars in boxes denote \pm one standard deviation, which indicates the variability in the 307 BC concentrations measured each month. The monthly-averaged BC concentrations for the 308 entire analyzed period were $4.0 \pm 2.5$ and $4 \pm 3 \mathrm{mg} / \mathrm{m}^{2}$, for December and January, 309 respectively, and $1.6 \pm 1.2$ and $2.0 \pm 0.5 \mathrm{mg} / \mathrm{m}^{2}$ for July and August, respectively, in 310 agreement with typical values of European urban environment as reported by Shuster et al.

311 (2005). The average BC concentration in winter was more than three times that computed 312 in summer. The winter average BC concentration $\left(3.8 \pm 0.6 \mathrm{mg} / \mathrm{m}^{2}\right)$ was $30 \%$ higher than the 313 eight-year average $\left(2.9 \pm 0.9 \mathrm{mg} / \mathrm{m}^{2}\right)$ whereas the summer average $\mathrm{BC}$ concentration $314\left(1.9 \pm 0.3 \mathrm{mg} / \mathrm{m}^{2}\right)$ was $35 \%$ lower than the overall mean. This seasonal variation in $\mathrm{BC}$ 315 concentrations in atmospheric column is similar to the seasonal variations at ground level, 316 derived for other aerosol properties in the study area (Lyamani et al., 2010; Lyamani et al., 317 2011). The seasonal mean BC concentrations for the entire analyzed period were $3.8 \pm 0.6$, $3182.05 \pm 0.03,1.9 \pm 0.3$ and $3.4 \pm 0.2 \mathrm{mg} / \mathrm{m}^{2}$ for winter, spring, summer and autumn, 319 respectively. In the same way that other studies (e.g., Dey et al., 2006), BC concentration 
320 was assumed well mixed below the boundary layer height (h). Consequently, BC 321 concentration retrieved in the atmospheric columnar can be converted to surface $\mathrm{BC}$ 322 concentrations dividing by $h$. Typical $h$ values in this area were $1.4 \pm 0.2,1.7 \pm 0.3,2.0 \pm 0.6$ 323 and 1.6 $\pm 0.4 \mathrm{~km}$ for winter, spring, summer and autumn, respectively (Granados-Muñoz et 324 al., 2012). Thus, corresponding seasonal mean values of surface BC concentrations values 325 were $2.7,1.2,0.9$ and $2.2 \mu \mathrm{g} / \mathrm{m}^{3}$. Mean value retrieved in our study in winter was notably 326 lower that retrieved by Lyamani et al. (2011) at surface level in this season $\left(4.4 \mu \mathrm{g} / \mathrm{m}^{3}\right)$. 327 Additionally, seasonal BC concentration variability in the atmospheric column presented a 328 behavior similar to that found by Lyamani et al. (2011) at the surface level. Thus, BC 329 showed an evident smooth decreasing in warm seasons and slightly increasing in cold 330 seasons. The features of $\mathrm{BC}$ concentration in the atmospheric column is related to a 331 combination of synoptic patterns and their associated wind flows with air mass coming 332 from different source areas. Moreover, different emission rate by polluted urban sources 333 could also produce a lesser extent in the seasonal BC variability changes. The main $\mathrm{BC}$ 334 emission sources could be the diesel fuel combustion processes, such as motor vehicles, 335 which remain throughout the year, and domestic heating emission in winter time. Similar 336 seasonal variations in $\mathrm{BC}$ concentrations have been observed in other urban areas (e.g. 337 Ramachandran and Rajesh, 2007; Kirchstetter et al., 2008; Cao et al., 2009; Saha and 338 Despiau, 2009), with higher BC concentrations in winter. Theses authors attributed the high 339 BC concentrations in winter to the increase in anthropogenic activities associated with 340 domestic heating, in addition to unfavorable meteorological conditions like shallow 341 atmospheric boundary layer and low wind speed. 
342 The year-to-year evolution of the BC concentration from 2005 to 2012 is shown in Figure

343 3. The annual mean BC concentrations exhibited similar values during 2005 and 2006

$344\left(3.0 \pm 2.0\right.$ and $3.2 \pm 2.4 \mathrm{mg} / \mathrm{m}^{2}$, respectively), showing a notable increase in $2007(4.0 \pm 2.4$

$345 \mathrm{mg} / \mathrm{m}^{2}$ ). From 2008, a strong reduction is observed, reaching low BC concentrations in $3462009\left(1.0 \pm 0.7 \mathrm{mg} / \mathrm{m}^{2}\right)$ and $2010\left(1.4 \pm 1.1 \mathrm{mg} / \mathrm{m}^{2}\right)$. This annual $\mathrm{BC}$ reduction is in

347 agreement with the results reported by Lyamani et al. (2011). These authors associated this 348 BC concentration reduction with the effect of the economic crisis. In our study, the analysis 349 has been extended until 2012 confirming that annual mean BC concentration reduction 350 remained until 2010. The BC levels for 2011 and 2012 showed slight increasing with 351 annual mean values of $2.3 \pm 1.8$ and $2.5 \pm 1.8 \mathrm{mg} / \mathrm{m}^{2}$, respectively. Nevertheless, these two 352 years still showed BC values lower than those registered in the years previous to the start of 353 the economic crisis. The annual report offered by Energy National committee (www.cne.es) 354 indicates that the sales of combustibles derived from petrol dropped from 2007 to 2012 in 355 Granada. Thus, it is foreseeable that less BC particles emissions from these sources were 356 injected to the atmosphere in this period.

\section{$358 \quad 4.2 \mathrm{BC}$ concentration classification according to cluster analysis}

359 Changes in meteorological and synoptic conditions could affect the monthly evolution of 360 BC concentration for the study period. To analyze this issue, Figure 4 displays the monthly 361 mean temperature (Fig 4a), wind speed (Fig. 4b), and rainfall (Fig 4c) for Granada from 3622005 to 2012. Additionally, this figure also shows a plot (Fig 4d) with the BC concentration 363 versus wind speed range in order to analyze if the monthly evolution of BC concentrations 
364 was caused by changes in wind speed, since it is known that high wind speeds are

365 associated with low aerosol concentrations in the study area (Lyamani et al., 2008). In

366 general, mean wind speeds in the study area were higher in spring and summer seasons and

367 slightly lower in autumn and winter seasons (Fig.4b). Consequently, one may expect higher

368 BC concentrations in winter and autumn than in spring and summer (Figure 2). This

369 assumption is verified in Fig. 4d which shows low BC concentrations for high wind speed

370 classes. The low wind speed classes $0.1-0.3$ and $0.3-0.5 \mathrm{~m} / \mathrm{s}$ were the most representative of

371 Granada local emissions, being less influenced by regional and long range transport.

372 The influence of changes in air mass patterns on the monthly evolution BC concentrations

373 was also analyzed in detail. Fig. 5a shows the centroids of cluster classification coincident

374 with BC observation days from 2005 to 2012. The air mass types were classified according

375 to the cluster analysis. This plot displays that there were different air mass patterns during

376 the study period. Most of the air mass (34\%) corresponds to air mass from local and

377 regional origin (cluster 1). A rather significant fraction (31\%) corresponds to air mass from

378 northern direction (cluster 2), while those originated from Mediterranean area (cluster 3)

379 and Atlantic Ocean (cluster 4) were less frequent, 17\% and 19\%, respectively. Aerosol

380 aging and deposition processes were not included in the back trajectory analysis which

381 could slightly overestimate the role of long-range BC transport. In our study the estimation

382 of $\mathrm{BC}$ aging and deposition can become very difficult because $\mathrm{BC}$ aerosols came from two

383 different $\mathrm{BC}$ sources, anthropogenic $\mathrm{BC}$ and biomass burning $\mathrm{BC}$ emissions. The aging

384 process of anthropogenic BC may be faster than that of biomass burning BC (Shen et al., 385 2014). 
Monthly evolution of $\mathrm{BC}$ concentrations as function of the air mass pattern flows are

387 showed in Fig. 5b. Obviously, BC concentrations were strongly affected by the air mass

388 origin. In the analyzed period, the highest BC concentrations were observed for local air

389 mass (cluster 1) and the lowest concentrations were obtained during Atlantic air mass

390 arrivals (cluster 4). Intermediate BC concentrations were associated with Mediterranean

391 and Northern advections. Local BC sources are mainly dominated by traffic throughout the

392 year, with an additional contribution from residential heating during the winter. Titos et al.

393 (2014), in a study about different aerosol sources affecting to the aerosol concentration

394 levels in Granada, retrieved that anthropogenic aerosol predominantly affected the fine

395 fraction and the traffic is the main source to target in Granada throughout the year, but

396 especially in winter. However, biomass burning aerosol transported from Mediterranean

397 areas may also affect the BC concentration levels mainly in autumn. In this sense, Figure 6

398 shows the seasonal air mass frequency and BC concentration, respectively, according to the

399 cluster classification. The acceptable correlation between air mass frequency and BC

400 concentration for cluster 1 in winter (Fig. 6a and 6e) and autumn (Fig. 6d and 6h) indicates

401 that just when local air mass affected Granada, BC concentration levels were increased. Air

402 mass frequency included in cluster 2 showed good correlation with BC concentration in

403 winter (Fig. 6a and 6e) and spring (Fig. 6b and 6f). Therefore, part of the total BC load in

404 the atmospheric column in these seasons could be originated from urban-industrial aerosols

405 transported from north Spain and Europe. On the other hand, high BC concentrations were

406 found in autumn just when air mass frequency for cluster 3 was more elevated suggesting

407 that air masses coming from Mediterranean region transport biomass burning particles

408 towards Granada (Fig. 6d and 6h). 
409 In order to complete information about BC concentration for air masses were classified in 410 cluster 1 we show the wind rose diagrams in Figures $7 \mathrm{a}$ and $7 \mathrm{~b}$. These two plots show the 411 wind rose for the daytime, for the years 2005 to 2012 were separated in two categories, 412 high and low BC concentration levels, respectively. Southeasterly and south-southeasterly 413 winds dominate at high $\mathrm{BC}$ concentration values with a $28 \%$ and $25 \%$ combined 414 occurrence, respectively (Fig. 7a). Wind flowing from these directions crossed over the 415 highway surrounding the city. The wind rose shows that winds from the north-northeasterly 416 directions were the most frequent, when low $\mathrm{BC}$ concentration values were found for 417 cluster 1(Fig. 7b). The north-northeasterly wind occurred about $33 \%$ of the whole period. 418 Less frequent winds were from the northerly and northwesterly directions, with combined 419 occurrence around $23 \%$ and $14 \%$, respectively.

420 To evaluate the seasonal variability, Fig. 8 analyzes in detail two particular cases according 421 to two flow patterns (cluster 1 and 3). The high BC concentrations observed in winter were 422 likely due to the increase in BC emissions caused by the increase in anthropogenic 423 activities associated with domestic heating and road traffic as well as to unfavorable 424 meteorological conditions like shallow atmospheric boundary layer and low wind speed. 425 Figure 8a shows the surface pressure at mean sea level for 1 January 2012 generated by 426 NOAA Air Resources Laboratory (http://ready.arl.noaa.gov/). This plot is representative of 427 the conditions prevailing from 1 to 5 January when maximum BC concentrations were 428 found. Small pressure gradients took place over the Iberian Peninsula during these days 429 coinciding with a high-pressure system located over Spain. This situation blocks the entry 430 of air masses from the Atlantic and promotes stagnation conditions, reducing the ventilation 431 of the atmosphere. The pressure gradient at the surface over the Iberian Peninsula was very 
432 low and, consequently, there was an absence of wind with cloudless and dry conditions. On

433 the other hand, part of the BC concentration found in Granada mainly in autumn could be

434 related to biomass burning transported from Centre-Europe and Mediterranean region. In

435 this sense, high BC concentrations were found in September in 2008 when air masses were

436 coming from different European-Mediterranean areas transporting biomass burning aerosol

437 from different forest fires in this region. From 22 August to the end of this month 2008

438 western Iberian Peninsula, south France and north Italy suffered numerous forest fires (see

439 http://maps.geog.umd.edu, and www.fire.uni-freiburg.de). Back trajectory analysis shows

440 that, at least at two altitudes, the study area was affected by European-Mediterranean air

441 masses. According to the NAAPS aerosol transport model the multiple forest fires in

442 different regions in southern Europe, especially in Italy (http://maps.geog.umd.edu) and the

443 associated anticyclonic situation favored rather high levels of smoke over the whole Iberian

444 Peninsula and much of the Mediterranean basin during this period. Thus, the wind flows

445 that arrived at study area at 500 and $1500 \mathrm{~m}$ could have transported biomass burning

446 particles and/or urban-industrial aerosols originated in south Europe (Fig. 8b).

\section{$447 \quad 4.3$ Shortwave aerosol radiative forcing}

448 Aerosol optical properties and radiative forcing values were separately derived for 449 composite aerosol and for BC as explained previously. The evolution of the monthly mean 450 values of the daily radiative forcing for composite aerosols (equation 8) from 2005 to 2012

451 is shown in Figure 9a. This plot shows the monthly forcing values at surface and TOA 452 together with the variation of the atmospheric radiative forcing derived from the difference 453 between the surface and TOA forcing values (e.g, Valenzuela et al., 2012). Composite 
aerosol radiative forcing at the surface $\left(\mathrm{ARF}_{\text {Surf }}\right)$ was higher during warm season (up to -

$45528 \pm 8 \mathrm{~W} / \mathrm{m}^{2}$ in August), which may be due to larger AOD values recorded during these

456 months. Thus, ARF $\mathrm{Aur}_{\text {was }}$ well correlated with the observed AODs. The highest monthly

457 mean values of the aerosol radiative forcing at the TOA ( $\left.\mathrm{ARF}_{\mathrm{TOA}}\right)$ were retrieved in spring

458 and early summer with the highest monthly value in May $\left(4 \pm 2 \mathrm{~W} / \mathrm{m}^{2}\right)$. Positive $\mathrm{ARF}_{\mathrm{TOA}}$

459 indicates a net warming effect, which mainly arises due to highly reflecting continental

460 surface albedo and strong aerosol absorption. ARFTOA may be affected by other optical

461 parameters such as single scattering albedo, $\omega$ (Kedia et al., 2016). The $\omega$ values were

462 lower for composite aerosol during spring and summer, indicating enhanced presence of

463 absorbing particles during this period (not shown). Negative values of the ARF Surf $_{\text {indicate }}$

464 a cooling effect, while positive values of the $\mathrm{ARF}_{\mathrm{TOA}}$ suggest less radiation scattered into

465 space. The difference between $\mathrm{ARF}_{\mathrm{TOA}}$ and $\mathrm{ARF}_{\text {Surf }}$ provides the atmospheric radiative

466 forcing for composite aerosol $\left(\mathrm{ARF}_{\mathrm{Atm}}\right)$, which showed the same pattern that ARF Surf with

467 larger mean values in summer (up to $30 \pm 3 \mathrm{~W} / \mathrm{m}^{2}$ in July).

468 The AOD (440 nm) obtained exclusively for BC aerosol showed values ranging between

4690.01 and 0.05 (not shown), contributing to about $10-15 \%$ of the composite AOD. To

470 determine the impact of $\mathrm{BC}$ aerosol on the Earth-atmosphere radiation budget over

471 Granada, radiative forcing for BC aerosols is evaluated (equation 9) and compared to the

472 forcing for composite aerosol. Similarly, figure $9 \mathrm{~b}$ shows monthly values of forcing at

473 surface $\left(\mathrm{BCRF}_{\text {Surf }}\right)$, TOA $\left(\mathrm{BCRF}_{\mathrm{TOA}}\right)$ and atmosphere $\left(\mathrm{BCRF}_{\mathrm{Atm}}\right)$ estimated exclusively for

474 BC aerosol over the station. In this study the magnitude of the AOD (not shown) and

475 concentration of $\mathrm{BC}$ were relatively higher during winter(mean $\mathrm{AOD}=0.05 \pm 0.02$ mean

$476 \mathrm{BC}=3.8 \pm 0.6 \mathrm{mg} / \mathrm{m}^{2}$ ) than for other seasons. 
477 It can be seen that $\mathrm{BC}$ radiative forcing exhibits a similar pattern with lower values at 478 surface and higher values at TOA as compared to those for composite aerosol during the 479 entire period. In contrast to composite aerosol, $\mathrm{BCRF}_{\mathrm{TOA}}$ exhibited similar pattern as $\mathrm{BC}$ 480 AOD because $\mathrm{BC}$ and $\omega(\lambda)$ values showed no significant changes during all seasons (not 481 shown). Estimated monthly mean $\mathrm{BCRF}_{\mathrm{TOA}}$ was high in during summer (up to $+7.5 \pm 0.7$ $482 \mathrm{~W} / \mathrm{m}^{2}$ in July). During the whole period, BCRF 483 warming effect due to the absorption of solar radiation by $\mathrm{BC}$ aerosol. In addition,

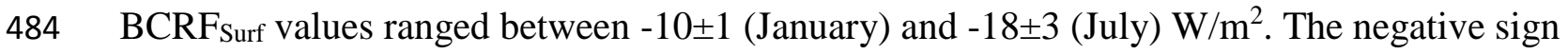
485 of forcing values observed at the surface implies a net cooling effect. Finally, the positive $486 \mathrm{BCRF}_{\mathrm{Atm}}$ values (between $+13 \pm 1$ and $+26 \pm 3 \mathrm{~W} / \mathrm{m}^{2}$ ) indicate a net warming effect in the 487 atmosphere. This positive forcing represents a considerable amount of heating of the lower 488 atmosphere and has been conjectured as potential factor causing global warming during 489 winter (Jacobson, 2001).

490 The mean $\mathrm{ARF}_{\mathrm{Atm}}$ and $\mathrm{BCRF}_{\mathrm{Atm}}$ values, averaged over the entire period, were about $+23 \pm 6$ $491 \mathrm{~W} / \mathrm{m}^{2}$ and $+15 \pm 6 \mathrm{~W} / \mathrm{m}^{2}$, respectively. These forcing values are translated into a heating rate 492 of $+0.21 \pm 0.06 \mathrm{~K} /$ day (composite aerosol) and $+0.15 \pm 0.06 \mathrm{~K} /$ day $(\mathrm{BC}$ aerosol). Taking into 493 account only mean values of $\mathrm{ARF}_{\mathrm{Atm}}$ and $\mathrm{BCRF}_{\mathrm{Atm}}$, it can be seen that $\mathrm{BC}$ radiative forcing 494 in the atmospheric column contributed on average around $67 \%$ of total composite aerosol 495 forcing for the study period. This large contribution of BC induced atmospheric warming 496 together with cooling surface. This situation can lead to inversions inhibiting thermal 497 conventions and, in addition to a reduction in the process of cloud formation (Panicker et 498 al., 2013; Chou et al., 2002). There are few studies in the literature reporting contribution of 499 BC to composite aerosol radiative forcing (S. Ramachandran, S. Kedia, 2011; Arola et al., 
500 2015). For instance, Panicker et al. (2013) found a BC contribution of up to $88 \%$ in South

501 Korea. These same authors found lower BC contribution values in an urban India site of up 502 to $55 \%$.

503 In spite of the fact that our study was constrained to fine mode-dominate cases, ARF $F_{\text {Surf, }}$ $504 \mathrm{ARF}_{\mathrm{TOA}}$ and $\mathrm{ARF}_{\mathrm{Atm}}$ show values in the range of those found by other authors (Panicker et 505 al., 2010; Ramachandran and Kedia, 2010; Ramachandran et al., 2011). Valenzuela et al. 506 (2012b) focused on desert dust events over Granada station, reporting higher mean values 507 of aerosol radiative forcing at surface $\left(\sim-19 \pm 7 \mathrm{~W} / \mathrm{m}^{2}\right)$, negative mean aerosol radiative 508 forcing values at TOA $\left(\sim-6 \pm 5 \mathrm{~W} / \mathrm{m}^{2}\right)$, and lower mean values in the atmosphere $(\sim 14 \pm 7$ $509 \mathrm{~W} / \mathrm{m}^{2}$ ), during 2005-2010 period. Therefore, desert dust events contributed to diminish 510 atmospheric warming in Granada station. In contrast to composite aerosol forcing, 511 BCRF $_{\text {Surf, }} \mathrm{BCRF}_{\mathrm{TOA}}$ and $\mathrm{BCRF}_{\mathrm{Atm}}$ values were higher over Granada than in other regions 512 (Panicker et al., 2010; Panicker et al., 2013). These differences could be justified for the 513 methodological differences in retrieving BC concentration. Large database over closely 514 gridded stations are required in order to quantify the BC aerosol radiative effects over a 515 particular region. Nevertheless, in the present study we attempted to present the scenario of 516 seasonal $\mathrm{BC}$ aerosol radiative forcing due to the presence of $\mathrm{BC}$ aerosol over an urban 517 typical location on the southeastern Iberian Peninsula.

\section{Conclusions}

519 The BC concentration values presented in this study were retrieved for the period 2005520 2012. BC concentrations showed high average values in January $\left(4.0 \pm 2.6 \mathrm{mg} / \mathrm{m}^{2}\right)$ and 521 December $\left(4.2 \pm 3.3 \mathrm{mg} / \mathrm{m}^{2}\right)$ and low average values in July $\left(1.6 \pm 1.2 \mathrm{mg} / \mathrm{m}^{2}\right)$ and August 
$522\left(2.0 \pm 0.6 \mathrm{mg} / \mathrm{m}^{2},\right)$. The winter average BC concentration $\left(3.8 \pm 0.7 \mathrm{mg} / \mathrm{m}^{2}\right)$ was $30 \%$ higher 523 than the eight-year average $\left(2.9 \pm 0.9 \mathrm{mg} / \mathrm{m}^{2}\right)$ whereas the summer average $\mathrm{BC}$ 524 concentration $\left(1.9 \pm 0.3 \mathrm{mg} / \mathrm{m}^{2}\right)$ was $35 \%$ lower than the overall mean. The reduction in the 525 use of fossil fuels due to economic crisis contributed significantly to reduce BC particles 526 injected to the atmosphere. According to our analysis this situation persisted until 2010. Air 527 masses arriving from four different sectors labeled cluster 1 (local), cluster 2 (north Spain528 south Europe), cluster 3 (Mediterranean region) and cluster 4 (Atlantic Ocean) exhibited 529 different $\mathrm{BC}$ concentrations. The $\mathrm{BC}$ concentration in cluster 1 showed high correlation 530 with air masses frequency of this cluster in winter and autumn. In these seasons BC the 531 traffic source is combined with emissions by domestic heating that were accumulated in the 532 rather shadow boundary layer. High BC concentrations were found in autumn just when air 533 masses frequency for cluster 3 was larger, thus suggesting that air masses coming from 534 Mediterranean region transported biomass burning particles towards Granada. The analysis 535 of a particular case confirm that air masses coming from Europe-Mediterranean region are 536 responsible of the transport of biomass burning particles just when numerous forest fires 537 affected southern France and northern Italy. The lowest BC concentration was associated 538 with the strongest influence of Atlantic Ocean air masses influence, really frequent during 539 spring and summer. The influence of air masses was evident in the BC concentration values 540 and it should be considered when assessing the influence of BC concentrations.

541 BC optical properties were retrieved from BC fraction together with aerosol AERONET 542 size volume distribution values under the assumption of spherical shape (Mie theory). 543 Aerosol optical properties for composite aerosol (including only fine mode-dominated 544 cases) were derived from AERONET network in agreement with those BC retrievals. BC 
545 and composite aerosol optical properties were used as input in SBDART model in order to 546 obtain radiative forcing values. The mean atmospheric aerosol radiative forcing for 547 composite aerosol, averaged for the entire period, was $+23 \pm 6 \mathrm{~W} / \mathrm{m}^{2}$ (which translates into a 548 heating rate of $+0.21 \pm 0.06 \mathrm{~K} /$ day) and $+15 \pm 6 \mathrm{~W} / \mathrm{m}^{2}$ for $\mathrm{BC}$ aerosol (which translates into a 549 heating rate of $+0.15 \pm 0.06 \mathrm{~K} /$ day). $\mathrm{BC}$ radiative forcing in the atmospheric column 550 contributed on average around $67 \%$ of total composite aerosol forcing for the study period 551 taking into account only mean values of $\mathrm{ARF}_{\mathrm{Atm}}$ and $\mathrm{BCRF}_{\mathrm{Atm}}$, This large contribution of 552 BC induced atmospheric warming together with cooling surface.

553 ACKNOWLEDGMENTS - This work was supported by the Andalusia Regional

554 Government through project P12-RNM-2409, by the Spanish Ministry of Economy and 555 Competitiveness through projects CGL2013-45410-R and CGL2016-81092-R and by the 556 European Union's Horizon 2020 research and innovation programme through project 557 ACTRIS-2 (grant agreement No 654109). The authors thankfully acknowledge the FEDER 558 program for the instrumentation used in this work. Antonio Valenzuela thanks Universidad 559 de Granada for the award of a postdoctoral grant ("Plan Propio. Programa 8. Convocatoria 560 2014"). The work is co-funded by the European Union through the European Regional 561 Development Fund, included in the COMPETE 2020 (Operational Program 562 Competitiveness and Internationalization) through the ICT project (UID / GEO / 563 04683/2013) with the reference POCI-01-0145-FEDER-007690. CIMEL Calibration was 564 performed at the AERONET-EUROPE calibration center, supported by ACTRIS 565 (European Union Seventh Framework Program (FP7/2007-2013) under grant agreement no. 566 262254. The authors express gratitude to the NOAA Air Resources Laboratory (ARL) for 567 the HYSPLIT transport and dispersion model (http://ready.arl.noaa.gov/HYSPLIT.php). 


\section{REFERENCES}

570 Ackerman, A. S., Toon, O. B., Stevens, D. E., Heymsfield, A. J., Ramanathan, V., and

571 Welton, E. J., 2000. Reduction of tropical cloudiness by soot, Science, 288(5468), 1042-

572 1047, doi:10.1126/science.288.5468.1042.

573 Antón, M., Valenzuela, A., Cazorla, A., Gil, J. E., FernándezGálvez, J., Lyamani, H., Foyo-

574 Moreno, I., Olmo, F. J., and Alados-Arboledas, L., 2012. Global and diffuse shortwave 575 irradiance during a strong desert dust episode at Granada (Spain), Atmos. Res., 118, 232576 239, doi:10.1016/j.atmosres.2012.07.007.

577 A. Arola, G.L. Schuster, M.R.A. Pitkänen, O. Dubovik, H. Kokkola, A.V. Lindfors, T. 578 Mielonen, T. Raatikainen, S. Romakkaniemi, S.N. Tripathi, H. Lihavainen, 2015. Direct 579 radiative effect by brown carbon over the Indo-Gangetic Plain Atmos Chem Phys, pp. 580 12731-12740 http://dx.doi.org/10.5194/acp-15-12731-2015.

581 Arola, A., Schuster, G., Myhre, G., Kazadzis, S., Dey, S. and Tripathi, S. N., 2011. 582 Inferring absorbing organic carbon content from AERONET data. Atmos. Chem. Phys. $583 \quad 215-225$.

584 Balkanski, Y. J., D. J. Jacob, G. M. Gardner, W. C. Graustein, and K. K. Turekian. 1993. 585 Trans-port and residence times of tropospheric aerosols inferred from a global three586 dimensional simulation of 210Pb, J. Geophys. Res., 98, 20,573-20,586.

587 Babu, S.S., Satheesh, S.K., Krishna Moorthy, K., 2002. Enhanced aerosol radiative forcing 588 due to aerosol black carbon at an urban site in India. Geophys. Res. Let. 29, 589 http://dx.doi.org./10.1029/2002GL015826.

590 Bond, T. C., D. G. Streets, K. F. Yarber, S. M. Nelson, J.-H. Woo, and Z. Klimont, 2004. A 591 technology-based global inventory of black and organic carbon emissions from 592 combustion, J. Geophys. Res., 109, D14203, doi:10.1029/2003JD003697.

593 Bond, T.C., Doherty, S.J., Fahey, D.W., Forster, P.M., Berntsen, T., DeAngelo, B. J., 594 Flanner, M.G., Ghan, S., Kärcher, B., Koch, D., Kinne, S., Kondo, Y., Quinn, P.K., 595 Sarofim, M.C., Schultz, M.G., Schulz, M., Venkataraman, C., Zhang, H., Zhang, S., 596 Bellouin, N., Guttikunda, S. K., Hopke, P. K., Jacobson, M.Z., Kaiser, J.W., Klimont, Z., 597 Lohmann, U., Schwarz, J.P., Shindell, D., Storelvmo, T., Warren, S.G. and Zender, C.S., 598 2013. Bounding the role of black carbon in the climate system: A scientific assessment. J. 599 Geophys. Res. doi:10.1002/jgrd.50171. 
600

601

602

603

604

605

606

607

608

609

610

611

612

613

614

615

616

617

618

619

620

621

622

623

624

625

626

627

628

629

630

631

632

Bohren, C.F., Huffman, D.R., 1998. Absorption and Scattering of Light by Small Particle. Wiley, New York.

Bush, B.C., and Valero, F.P.J., 2003. Surface aerosol radiative forcing at Gosan during the ACE-Asia campaign, J. Geophys. Res. 108, D23, 8660, doi: 10.1029/2002JD003233.

Cao, J., Zhu, C., Chow, J.C.,Watson, J.G., Han, Y.,Wang, G., Shen, Z., An, Z., 2009. Black carbon relationships with emissions and meteorology in Xi'an, China. Atmos. Res. 94, 194202.

Chou, M. D., Chan, P. K. and Wang, M., 2002. Aerosol radiative forcing derived from sea WiFS retrieved aerosol optical properties. J. Atmos. Sci. 59, 748-757.

Chung, S. H., and J. H. Seinfeld, 2005. Climate response of direct radiative forcing of anthropogenic black carbon, J. Geophys. Res., 110, D11102, doi:10.1029/2004JD005441.

Cachorro, V.E., C. Toledano, N. Prats, M. Sorribas, S. Mogo, A. Berjón, B. Torres, R. Rodrigo, J. de la Rosa, and A. M. De Frutos, 2008. The strongest desert dust intrusion mixed with smoke over the Iberian Peninsula registered with Sun photometry, J. Geophys. Res. 113, D14S04, doi:10.1029/2007JD009582.

Dey, S., Tripathi, S. N., Singh, R. P. and Holben, B., 2006. Retrieval of black carbon and specific absorption over Kanpur city, Northern India during 2001-2003 using AERONET data. Atmos. Environ. 40(3), 445-456.

Derimian, Y., Karnieli, A., Kaufman, Y.J., Andreae, M.O., Andreae, T.W., Dubovik, O., Maenhaut, W., Koren, I., 2008. The role of iron and black carbon in aerosol light absorption. Atmos.Chem.Phys. 8, 3623-3637.

Dubovik, O., Smirnov, A., Holben, B.N., King, M.D., Kaufman, Y.J., Eck, T.F., I. Slutsker, I., 2000. Accuracy assessment of aerosol optical properties retrieved from Aerosol Robotic Network (AERONET) Sun and sky radiance measurements, J. Geophys. Res. 105, D8, 9791-9806.

Dubovik, O., Sinyuk, A., Lapyonok, T., Holben, B.N., Mishchenko, M., Yang, P., Eck, T.F., Volten, H., Muñoz, O., Veihelmann, B., van der Zande, W.J., Leon, J.F., Sorokin, M., Slutsker, I., 2006. Application of spheroid models to account for aerosol particle nonsphericity in remote sensing of desert dust. J. Geophys. Res. 111, D11208, doi:10.1029/2005JD006619, 2006.

Dubovik, O., and King M. D., 2000. A flexible inversion algorithm for retrieval of aerosol optical properties from sun and sky radiance measurements, J. Geophys. Res. 105, 20,67320,696 . 
633

634

635

636

637

638

639

640

641

642

643

644

645

646

647

648

649

650

651

652

653

654

655

656

657

658

659

660

661

662

663

664

Draxler, R.R., Hess, G.D., 1998. An overview of the HYSPLIT_4 modelling system for trajectories, dispersion and deposition. Aust. Meteorological Mag. 47, 295-308.

Draxler, R. R., B. Stunder, G. Rolph, and A. Taylor (2009), HYSPLIT_4 User's Guide, NOAA Air Resour. Lab., Silver Spring, Md.

Eck, T. F., Holben, B. N., Reid, J. S., Dubovik, O., Smirnov, A., O’Neill, N. T., Slutsker, I., and Kinne, S., 1999. Wavelength dependence of optical depth of biomass burning, urban, and desert dust aerosols, J. Geophys. Res. 104, 31 333-31 349.

Estellés, V., Martinez-Lozano, J.A., Utrillas, M.A.P., 2007. Influence of air mass history on the columnar aerosol properties at Valencia, Spain. J. Geophys. Res. 112, D15211, doi:10.1029/2007JD008593.

Granados-Muñoz, M. J., Navas-Guzman, F., Bravo-Aranda, J. A., Guerrero-Rascado, J. L., Lyamani, H. and co-authors. 2012. Automatic determination of the planetary boundary layer height using lidar: one-year analysis over southeastern Spain. J. Geophys. Res. Atmos. 117, D18208, 1-10.

Hansen, J., Sato, M., Ruedy, R., Lacis, A., and Oinas, V., 2000. Global warming in the twenty-first century: an alternative scenario, P. Natl. Acad. Sci. USA, 97, 9875-9880.

Harris, J., Draxler, R. R. and Oltmans, S. J., 2005. Trajectory model sensitivity to differences in input data and vertical transport method, J. Geophys. Res. 110, D14109, doi:10.1029/2004JD005750.

Haywood, J.M. and Shine, K.P. 1997. The effect of anthropogenic sulfate and soot aerosol on the clear sky planetary radiation budget. Geophys. Res. Lett. 22, 603-6.

Holben, B.N., Eck, T.F., Slutsker, I., Tanre, D., Buis, J.P., Setzer, A., Vermote, E., Reagan, J.A., Kaufman, Y.J., Nakajima, T., Lavenu, F., Jankowiak, I., Smirnov, A., 1998. AERONET - A federated instrument network and data archive for aerosol characterization. Remote Sens. Environ. 66, 1-16.

Jacobson, M. Z. 2001. Strong radiative heating due to mixing state of black carbon on atmospheric aerosols, Nature, 409, 695- 697.

Jacobson, M. Z., 2006. Effects of absorption by soot inclusions within clouds and precipitation on global climate, J. Phys. Chem., 110, 6860-6873.

Jacobson, M. Z., 2012. Investigating cloud absorption effects: Global absorption properties of black carbon, tar balls, and soil dust in clouds and aerosols, J. Geophys. Res., 117, D06205, doi:10.1029/2011JD017218. 
665

666

667

668

669

670

671

672

673

674

675

676

677

678

679

680

681

682

683

684

685

686

687

688

689

690

691

692

693

694

695

696

Johnson, B. T., K. P. Shine, and P. M. Forster, 2004. The semidirect aerosol effect: Impact of absorbing aerosols on marine stratocumulus, Q. J. Roy. Meteor. Soc., 130(599), 14071422, doi:10.1256/qj.03.61.

Jones, A., J.M. Haywood, and O. Boucher, 2007. Aerosol forcing, climate response and climate sensitivity in the Hadley Centre climate model, J. Geophys. Res., 112, D20211, doi:10.1029/2007JD008688.

Kanakidou, M., Seinfeld, J. H., Pandis, S. N., Barnes, I., Dentener, F. J., Facchini, M. C., Van Dingenen, R., Ervens, B., Nenes, A., Nielsen, C. J., Swietlicki, E., Putaud, J. P., Balkanski, Y., Fuzzi, S., Horth, J., Moortgat, G. K., Winterhalter, R., Myhre, C. E. L., Tsigaridis, K., Vignati, E., Stephanou, E. G., and Wilson, J., 2005. Organic aerosol and global climate modelling: a review, Atmos. Chem. Phys., 5, 1053-1123, doi:10.5194/acp-51053-2005.

Kedia S., Cherian R., Islam S., Das S.K. \& Kaginalkar A., 2016. Regional simulation of aerosol radiative effects and their influence on rainfall over India using WRFChem model. Atmos. Res., 182, 232-242.

Keil, A., Wendisch, M., Brüggemann, E., 2001. Measured profiles of aerosol particle absorption and its influence on clear-sky solar radiative forcing. J. Geophys. Res. 106, 1237-1247.

Kirchstetter, T. W., Novakov, T., Hobbs, P. V., 2004. Evidence that the spectral dependence of light absorption by aerosols is affected by organic carbon. J. Geophys. Res. 109, D21208, http://dx.doi.org/10.1029/2004JD004999.

Kirchstetter, T.W., Aguiar, J., Tonse, S., Fairley, D., Novakov, T., 2008. Black carbon densities and diesel vehicle emission factors derived from coefficient of haze measurements in California: 1967e2003. Atmos. Environ. 42, 480-491.

Kokkalis P., Amiridis V., Allan J.D., Papayannis A., Solomos S., Binietoglou I., Bougiatioti A., Tsekeri A., Nenes A., Rosenberg P.D., Marenco F., Marinou E., Vasilescu J., Nicolae D., Coe H., Bacak A. \& Chaikovsky A., 2017. Validation of LIRIC aerosol concentration retrievals using airborne measurements during a biomass burning episode over Athens. Atmos. Res. 183, 255-267.

Koch, D. and Del Genio, A. D., 2010. Black carbon semi-direct effects on cloud cover: review and synthesis, Atmos. Chem. Phys., 10, 7685-7696, doi:10.5194/acp-10-7685-2010. 
697

698

699

700

701

702

703

704

705

706

707

708

709

710

711

712

713

714

715

716

717

718

719

720

721

722

723

724

725

726

727

728

729
Kumar Bharath, d. and S. Verma, 2016. Potential emission flux to aerosol pollutants over Bengal Gangetic plain through combined trajectory clustering and aerosol source fields analysis, Atmos. Res. 178-179, http://dx.doi.org/10.1016/j.atmosres.2016.04.012.

Kumar M., Raju M.P., Singh R.K., Singh A.K., Singh R.S. \& Banerjee T., 2017. Wintertime characteristics of aerosols over middle Indo-Gangetic Plain: Vertical profile, transport and radiative forcing. Atmos. Res. 183, 268-282.

Liu, J. F., Fan, S. M., Horowitz, L. W., and Levy, H., 2011. Evaluation of factors controlling long-range transport of black carbón to the Arctic, J. Geophys. Res.-Atmos., 116, D04307, doi:10.1029/2010jd015145.

Lyamani, H., Olmo, F.J., Alados-Arboledas, L., 2008. Light scattering and absorption properties of aerosol particles in the urban environment of Granada, Spain. Atmos. Environ. 42, 2630-2642.

Lyamani, H., Olmo, F.J., Alados-Arboledas, L., 2010. Physical and optical properties of aerosols over an urban location in Spain: seasonal and diurnal variability. Atmos. Chem. Phys. 10, 239-254.

Lyamani, H., Olmo, F.J., Foyo, I. and Alados-Arboledas, L., 2011. Black carbón aerosols overa $n$ urban área in south-eastern Spain: Changes detected after the 2008 economic crisis. Atmos. Environ. 6423-6432.

Lyamani, H., Fernandez-Galvez, J., Perez-Ramirez, D., Valenzuela, A., Anton, M., Alados, I., Titos, G., Olmo, F.J., Alados-Arboledas, L., 2012. Aerosol properties over two urban sites in South Spain during an extended stagnation episode in winter season. Atmos. Environ. 62, 424-432. doi: 10.1016/j.atmosenv.2012.08.050.

Liou, K.N.: An introduction to Atmospheric Radiation. Elsevier, New York, 583 pp.

Olmo, F.J., Quirantes, A., Alcantara, A., Lyamani, H., Alados-Arboledas, L., 2006. Preliminary results of a non-spherical aerosol method for the retrieval of the atmospheric aerosol optical properties. J. Quant. Spectrosc. Radiat. Transfer. 100, 305-314.

Oshima, N., Koike, M., Zhang, Y., Kondo, Y., Moteki, N., Takegawa, N., and Miyazaki, Y., 2009. Aging of black carbon in outflow from anthropogenic sources using a mixing state resolved model: Model development and evaluation, J. Geophys. Res., 114, D06210, doi:10.1029/2008JD010680.

Panicker, A. S., G. Pandithurai, et al., 2010. On the contribution of black carbon to the composite aerosol radiative forcing over an urban environment. Atmos. Environ. 44(25), 3066-3070. 
Panicker, A. S., S.-H. Park, et al., 2013. Observations of Black Carbon characteristics and radiative forcing over a Global Atmosphere Watch supersite in Korea. Atmos. Environ. 77, 98-104.

Pereira, S.N., F. Wagner, and A.M. Silva, 2011. Seven years of measurements of aerosol scattering properties, near the surface, in the southwestern Iberia Peninsula, Atmos. Chem. Phys. 11, 17-29.

Prats, N., Cachorro, V.E., Sorribas, M., Mogo, S., Berjon, A., Toledano, C., De Frutos, A.M., de la Rosa, J., Laulainen, N., de la Morena, B.A., 2008. Columnar aerosol optical properties during "El Arenosillo 2004 summer campaign". Atmos. Environ. 42, 2643-2653.

S. Ramachandran, S. Kedia, 2011. Aerosol radiative effects over an urban location and a remote site in western India: seasonal variability. Atmos. Environ., 45, pp. 7415-7422.

Ramachandran, S., Rajesh, T.A., 2007. Black carbon aerosol mass densities over Ahmedabad, an urban location in western India: comparison with urban sites in Asia, Europe, Canada, and the United States. J. Geophys. Res. 112, D06211. doi:10.1029/2006JD007488.

Ramanathan, V. and Carmichael, G. 2008. Global and regional climate changes due to black carbon. Nature Geos. 1, 221-227. http://dx.doi.org/10.1038/ngeo156.

Ricchiazzi, P., S. Yang, C. Gautier, and D. Sowle., SBDART: A research and teaching software tool for plane-parallel radiative transfer in the Earth's atmosphere, Bull. Am. Meteorol. Soc., 79, 2101-2114, 1998.

Saha, A., Despiau, S., 2009. Seasonal and diurnal variations of black carbon aerosols over a Mediterranean coastal zone. Atmos. Res. 92, $27 \mathrm{e} 41$.

Schuster, G. L., Dubovik, O., Holben, B.N. and Clothiaux, E. E., 2005. Inferring black carbon content and specific absorption from Aerosol Robotic Network (AERONET) aerosol retrievals, J. Geophys. Res. 110, D10S17, doi:10. 1029/2004JD004548.

Shen, Z., Liu, J., Horowitz, L. W., Henze, D. K., Fan, S., H., L. I., Mauzerall, D. L., Lin, J.T., and Tao, S., 2014. Analysis of transpacific transport of black carbon during HIPPO-3: implications for black carbon aging, Atmos. Chem. Phys., 14, 6315-6327, doi:10.5194/acp14-6315-2014.

Silva, A.M ,Von Hoyningen-Huene, W., Bugalho, L., Schmidt,T., Costa, M.J., Heintzenberg, J. 2002. Aerosol Optical Properties from columnar data during ACE2 at the South Coast of Portugal. J. Geophys. Res. Vol.107, Nº D22 4642. 
762

763

764

765

766

767

768

769

770

771

772

773

774

775

776

777

778

779

780

781

782

783

784

785

786

787

788

789

790

791

792

Stohl, A., 1998. Computation, accuracy and applications of trajectories: A review and bibliography, Atmos. Environ. 32, 947-966.

G. Titos, H. Lyamani, M. Pandolfi, A. Alastuey, L. Alados-Arboledas, 2014. Identification of fine $\left(\mathrm{PM}_{1}\right)$ and coarse $\left(\mathrm{PM}_{10-1}\right)$ sources of particulate matter in an urban environment, Atmos. Environ., 89, pp. 593-602.

Toledano, C., Cachorro, V.E., de Frutos, A.M., Torres, B., Berjon, A., Sorribas, M., Stone, R.S., 2009. Airmass Classification and Analysis of Aerosol Types at El Arenosillo (Spain). J. Appl. Meteorol. Climatol. 48, 962-981.

Valenzuela, A., Olmo, F.J., Lyamani, H., Antón, M., Quirantes, A., Alados-Arboledas, L., 2012a. Classification of aerosol radiative properties during African desert dust intrusions over southeastern Spain by sector origins and cluster analysis, J. Geophys. Res. 117, D06214, doi:10.1029/2011JD016885.

Valenzuela, A., Olmo, F.J., Lyamani, H., Antón, M., Quirantes, A. and Alados-Arboledas, L., 2012b. Aerosol radiative forcing during African desert dust intrusions (2005-2010) over Southeaster Spain. Atmos. Chem. Phys. 12, 10331-10351.

Verma, S., Pani, S.K. and Bhanja, S.N., 2013. Sources and radiative effects of wintertime black carbon aerosols in an urban atmosphere in east India. Chemosphere, 90, 260-269.

Zhang, X. Y., Wang, Y. Q., Niu, T., Zhang, X. C., Gong, S. L., Zhang, Y. M., and Sun, J. Y., 2012. Atmospheric aerosol compositions in China: spatial/temporal variability, chemical signature, regional haze distribution and comparisons with global aerosols, Atmos. Chem. Phys., 12, 779-799, doi:10.5194/acp-12-779-2012.

Zdun A., Rozwadowska A. \& Kratzer S., 2016. The impact of air mass advection on aerosol optical properties over Gotland (Baltic Sea). Atmos. Res. 182, 142-155.

Zhao S., Tie X., Cao J. \& Zhang Q., 2015. Impacts of mountains on black carbon aerosol under different synoptic meteorology conditions in the Guanzhong region, China. Atmos. Res. 164-165, 286-296.

\section{FIGURES}

Figure 1: a) Location of Granada city and, b) radiometric station (CEAMA).

Figure 2: Monthly statistics of BC concentration over Granada from 2005 to 2012 represented as box diagrams. In these box diagrams, the mean is represented by a blank dot 
and the median by a middle line. The top/bottom box limits represent the percentiles $25 \%$ and $75 \%$. In addition, the error bars of the box are the percentiles $5 \%$ and $95 \%$. Number of observations is indicated between parentheses.

Figure 3: Evolution of monthly mean values of (a) Temperature $\left({ }^{\circ} \mathrm{C}\right)(\mathrm{b})$ wind speed $(\mathrm{m} / \mathrm{s})$ (c) rainfall $(\mathrm{mm})$ and $(\mathrm{d}) \mathrm{BC}$ concentrations as function of wind speeds at Granada from December 2005 to November 2008. The error bars are standard deviations.

Figure 4: Annual statistics of BC concentration over Granada from 2005 to 2012 represented as box diagrams. In these box diagrams, the mean is represented by a blank dot and the median by a middle line. The top/bottom box limits represent the percentiles $25 \%$ and $75 \%$. In addition, the error bars of the box are the percentiles $5 \%$ and $95 \%$.

Figure 5: (a) Centroids of cluster classification at $500 \mathrm{~m}$ level coincident with $B C$ observation days, and (b) BC concentrations as function of cluster classification from 2005 to 2012. The error bars are standard deviations.

Figure 6: a-d) Seasonally frequencies of air mass types according with cluster analysis that affected Granada from 2005 to 2012, e-h) seasonally BC concentration values according with cluster analysis that affected Granada from 2005 to 2012.

Figure 7: Wind rose plots for cluster 1 affecting to Granada place with (a) high BC concentration levels, (b) low BC concentration levels.

Figure 8: a) Synoptic chart of surface pressure at mean sea level for 1 January 2012, b) back trajectories ending at Granada at 12 UTC for altitude 500, 1500 and 3000m a.g.l. for 30 August 2008 representing days 22-30.

Figure 9: Radiative forcing at surface, TOA and in the atmosphere for a) Composite aerosol and b) $\mathrm{BC}$ aerosol.

政

(1)

(8)




\section{FIGURE 1}

a)

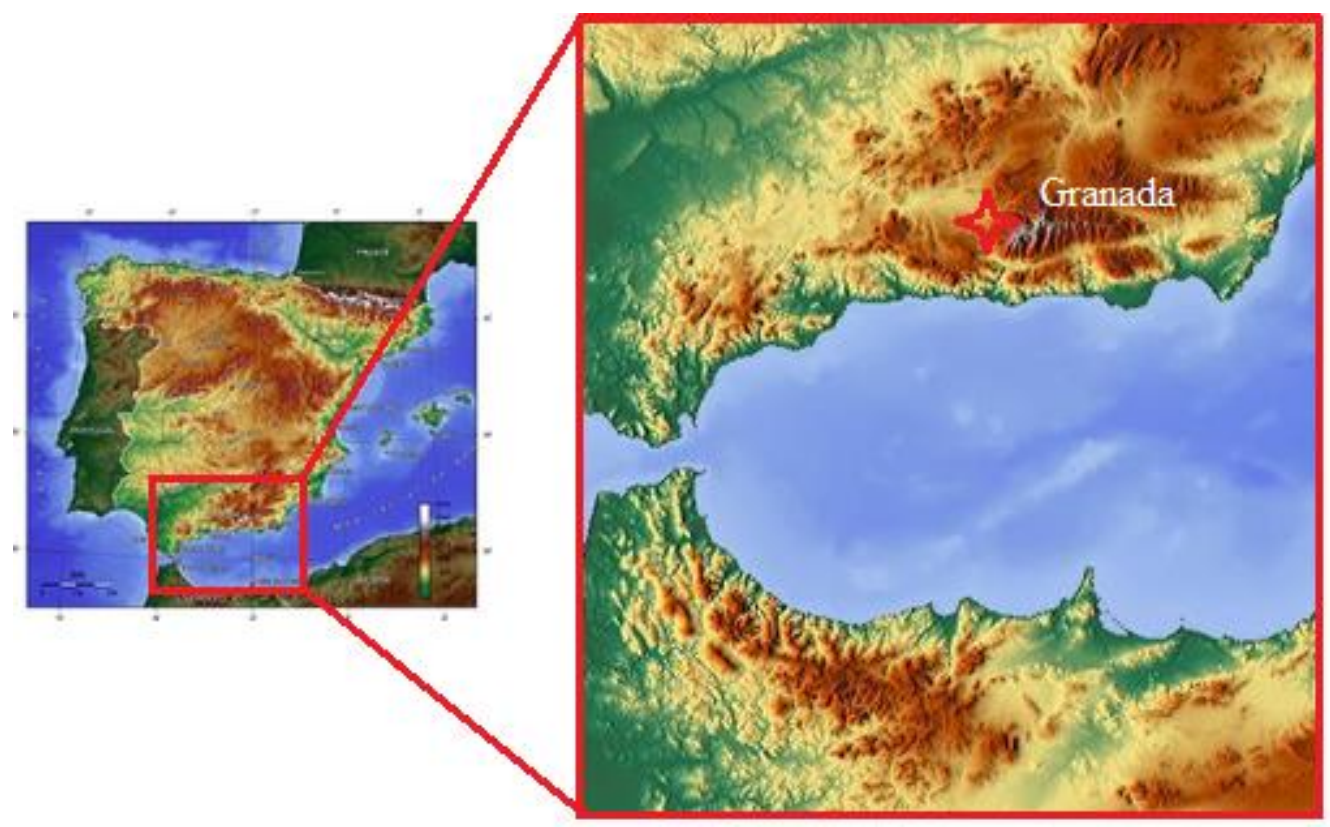

824 b)

825

826

827

828

829

830

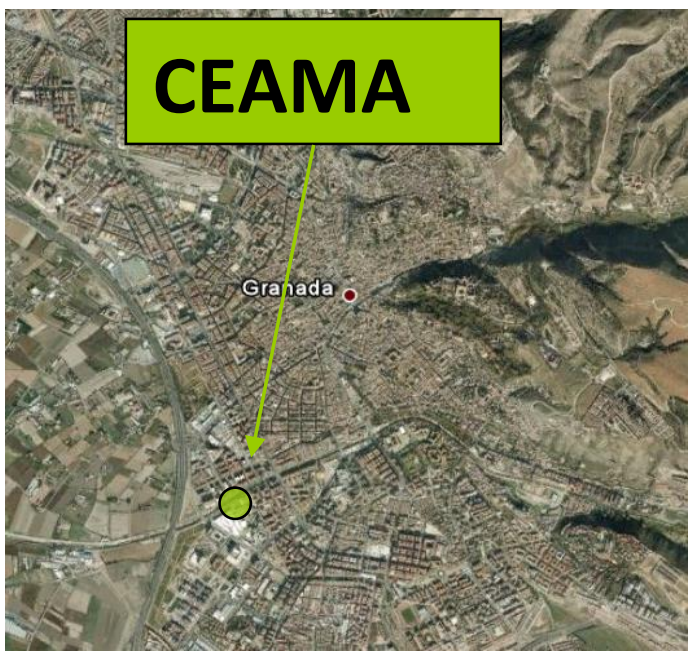

831 
833

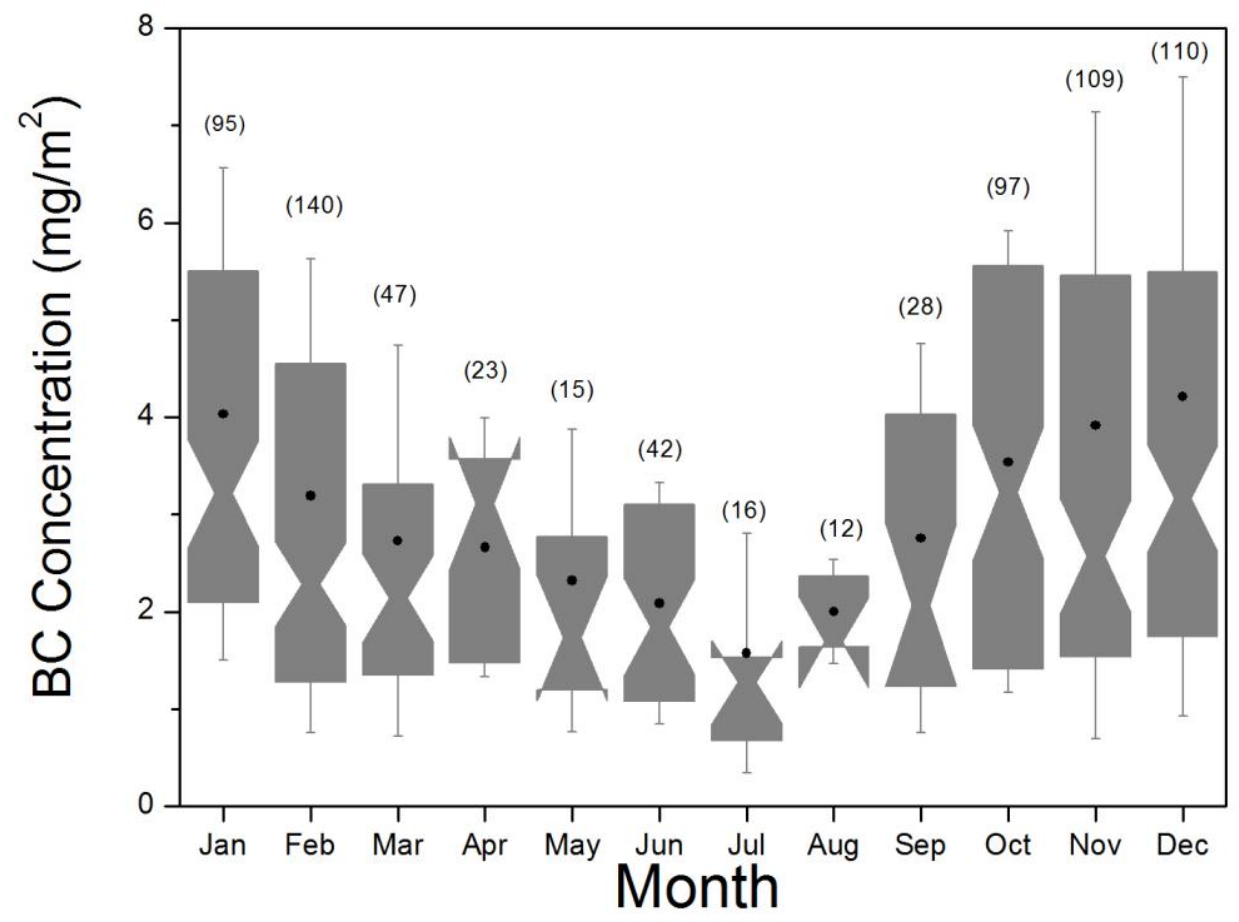

834

835

836

837

838

839

840

841

842

843 
845

846

847

848

849

850

851

852

853

854

855

856

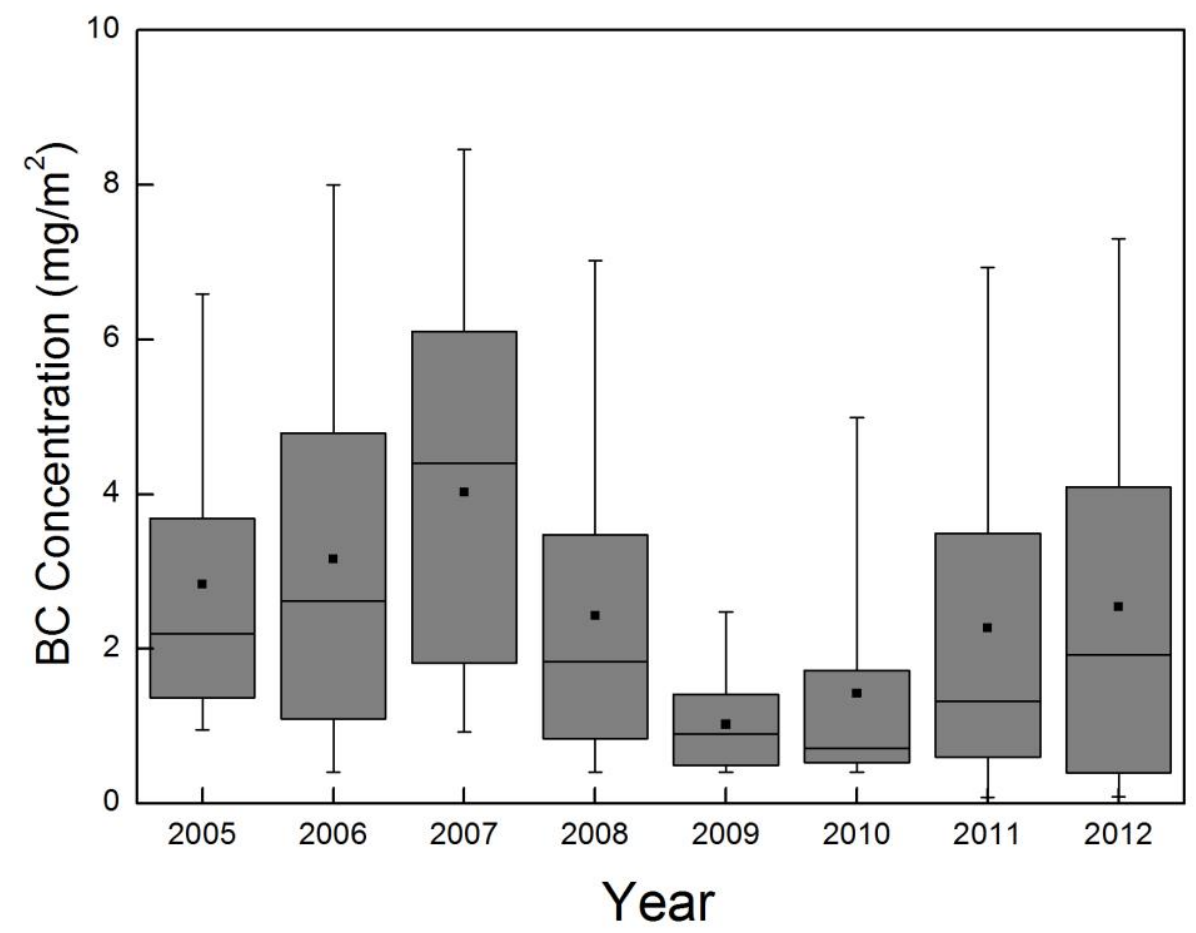

857

858 

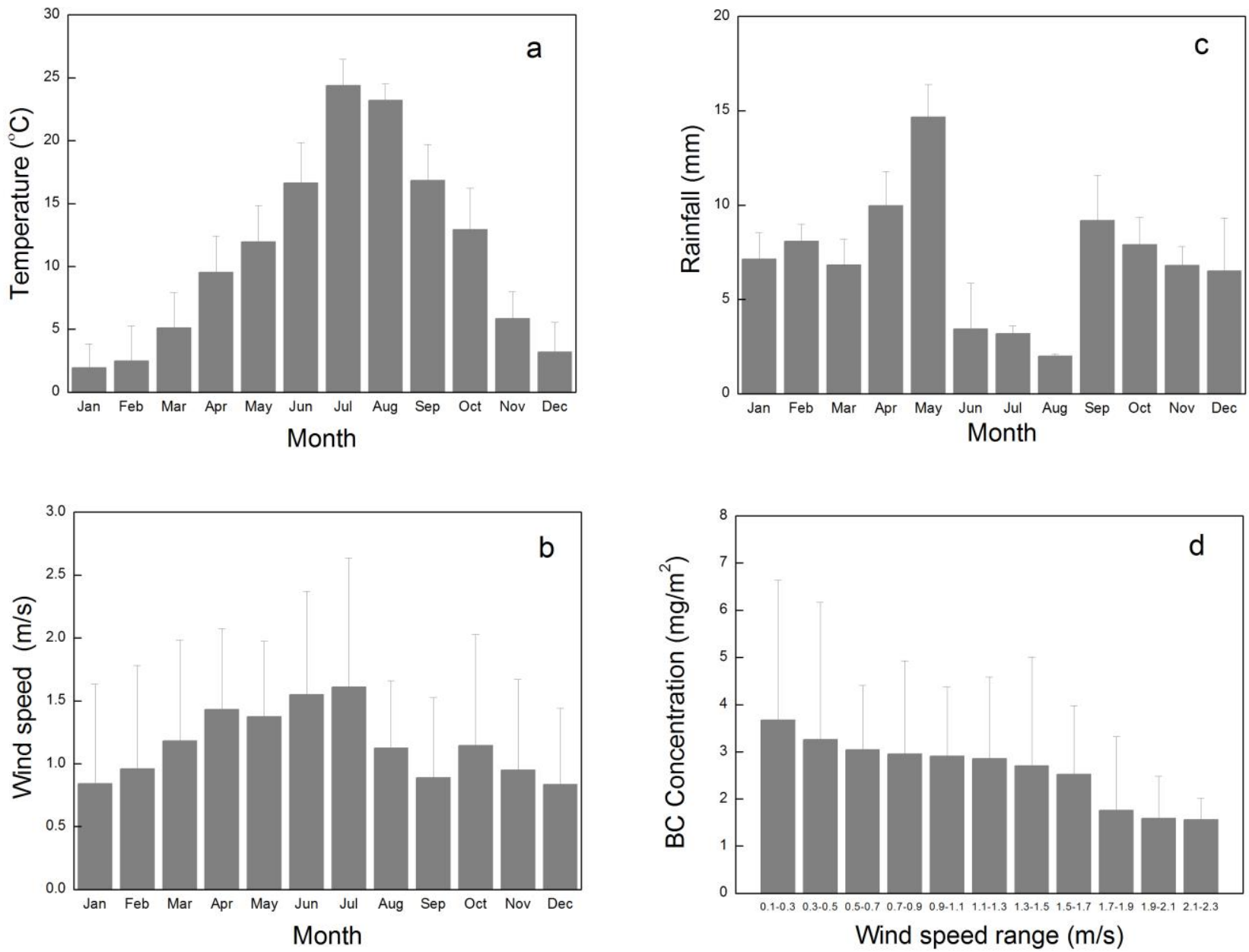
Cluster means - Standard 265 backward trajectories

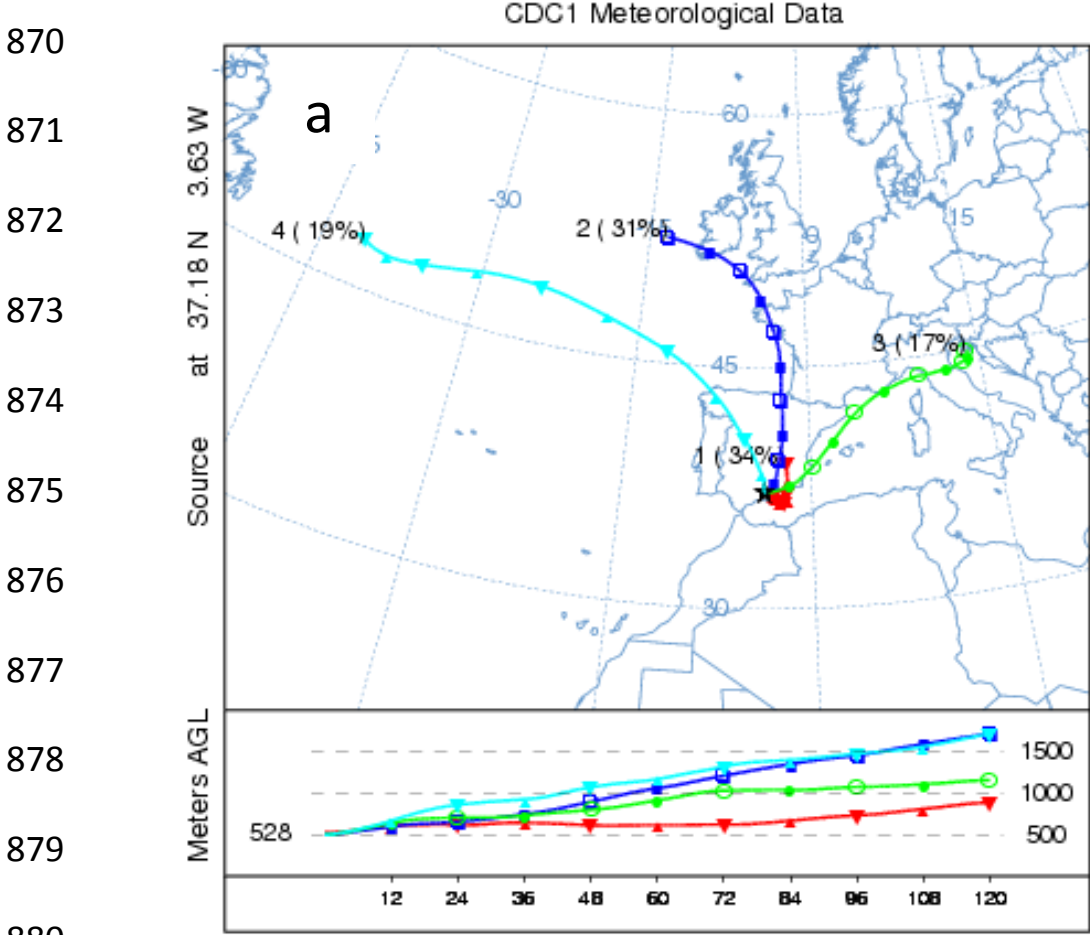

een

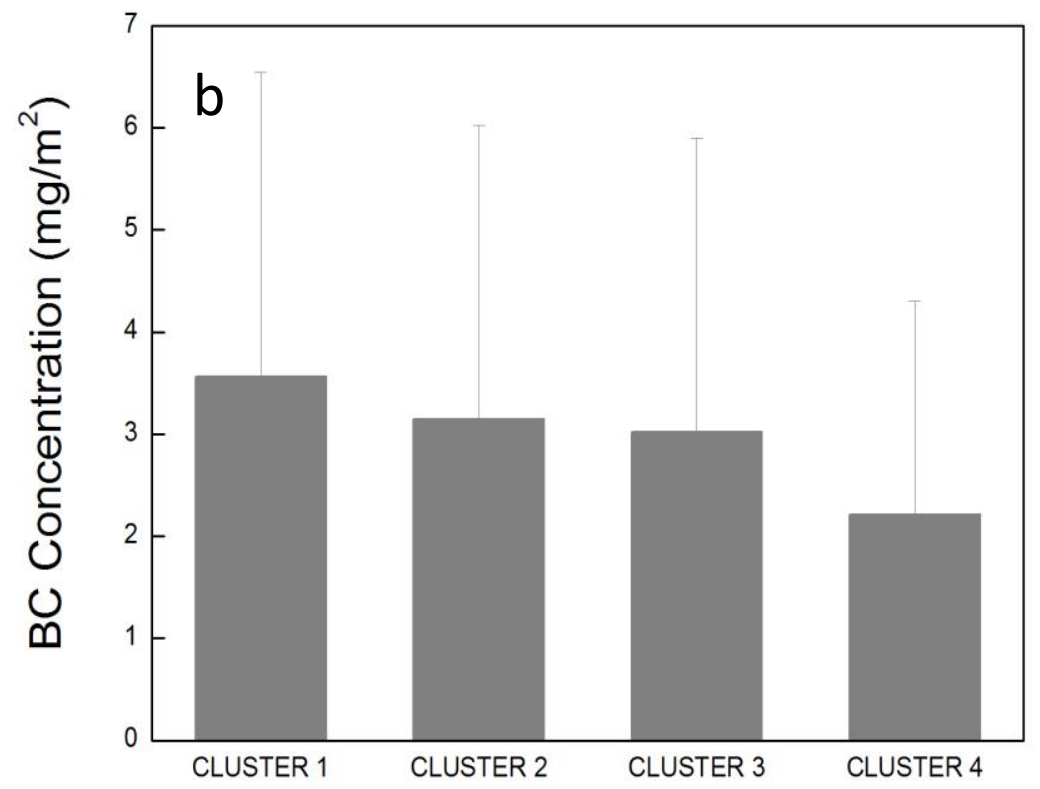


893

894

895

896

897

898

899

900

901

902

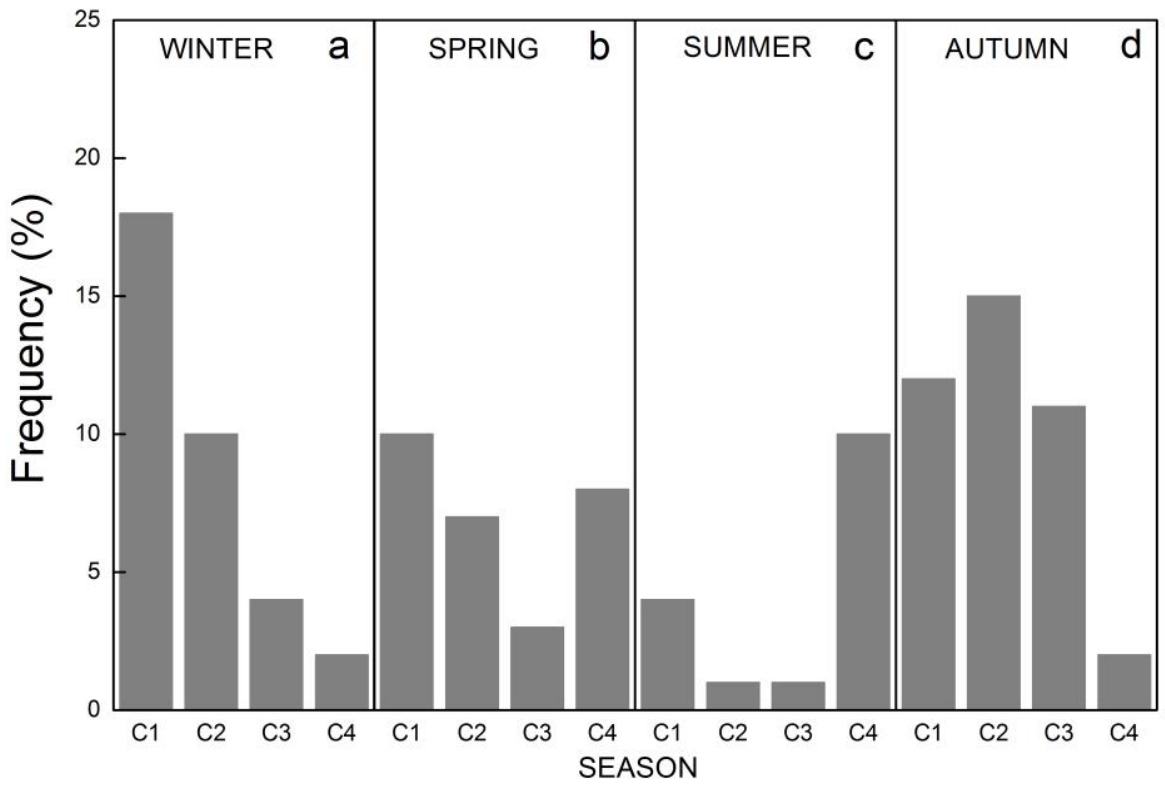

903

904

905

906

907

908

909

910

911

912

913

914

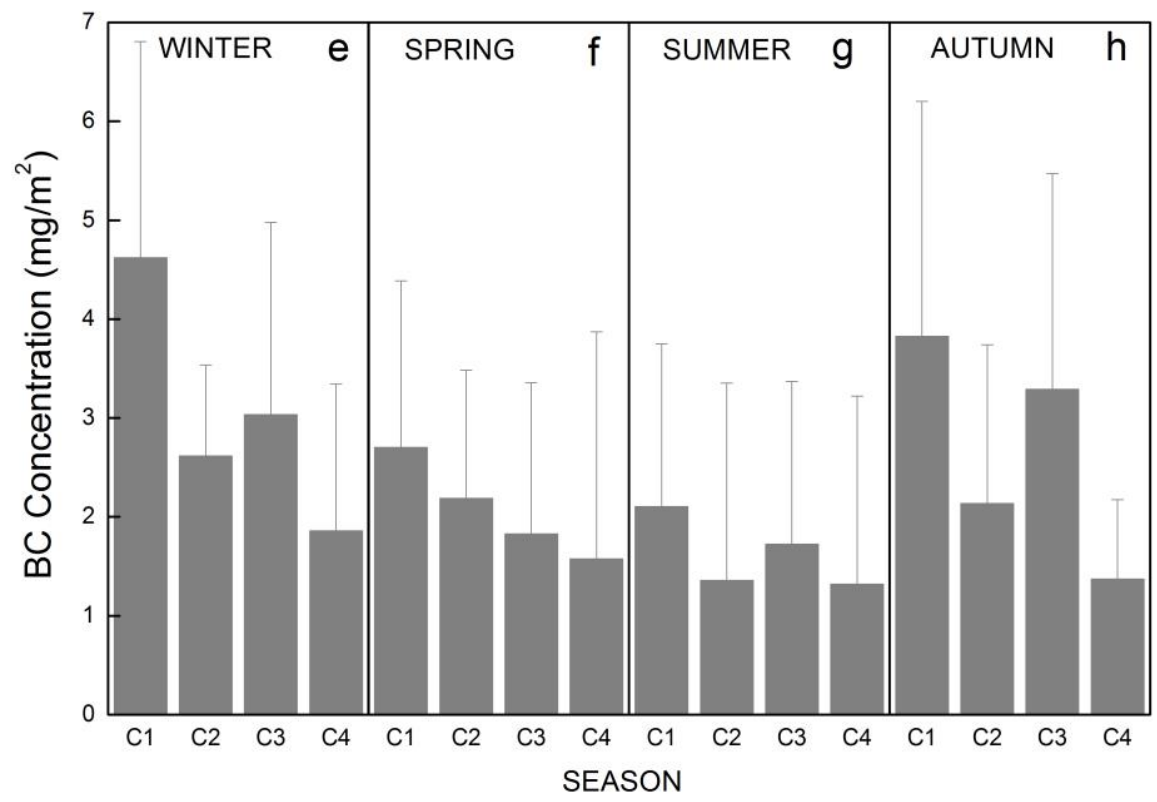

915 


\section{FIGURE 7}

917

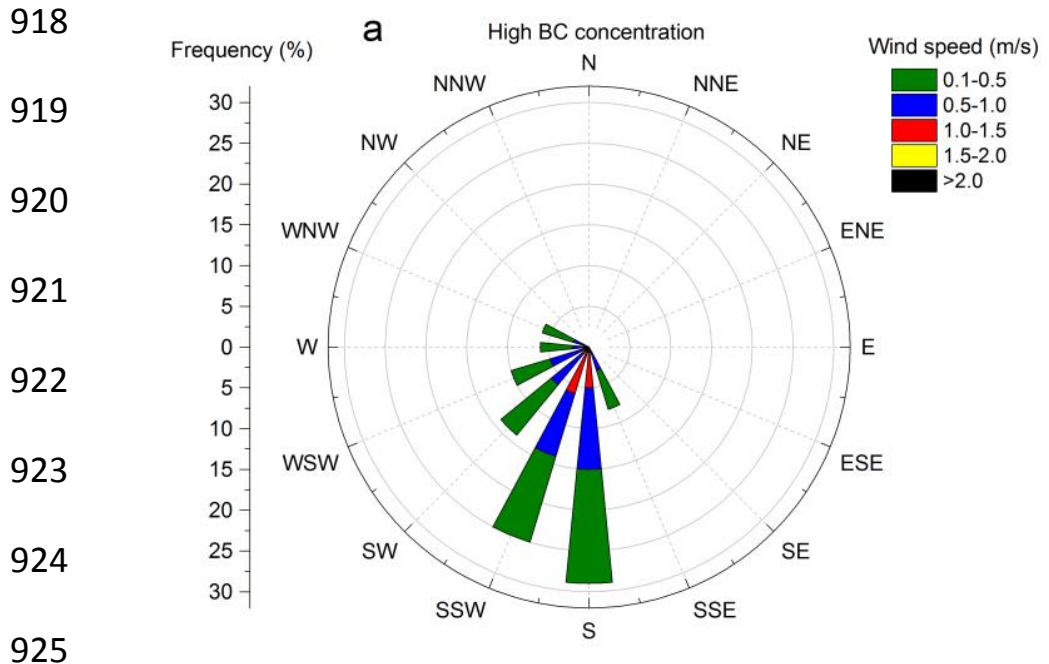

926

927

928

929

930

931

932

933

934

935

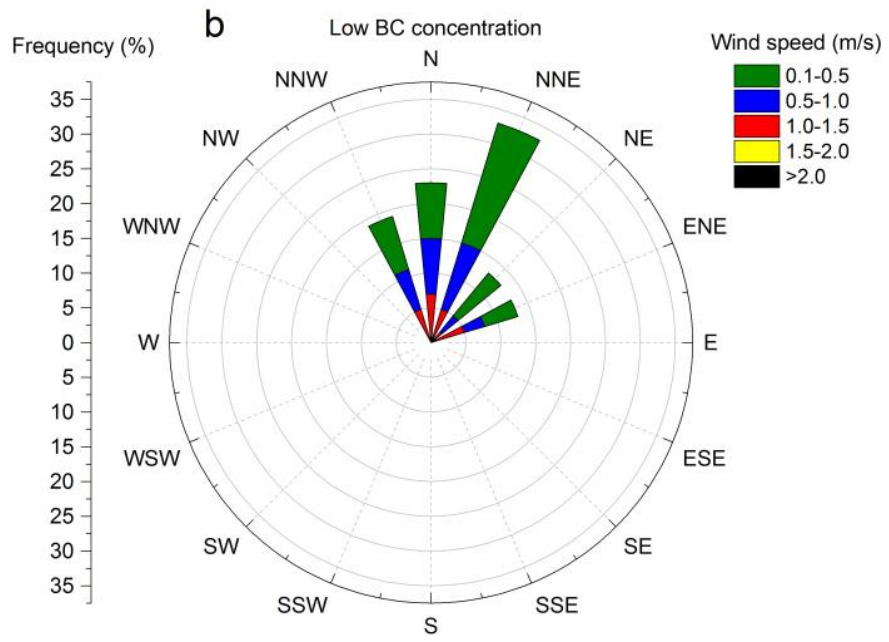

936

937

938

939 


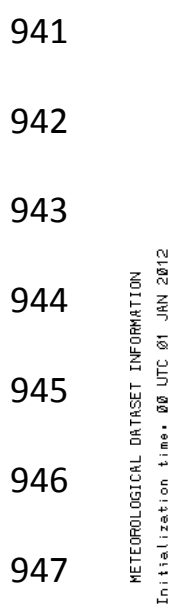

948

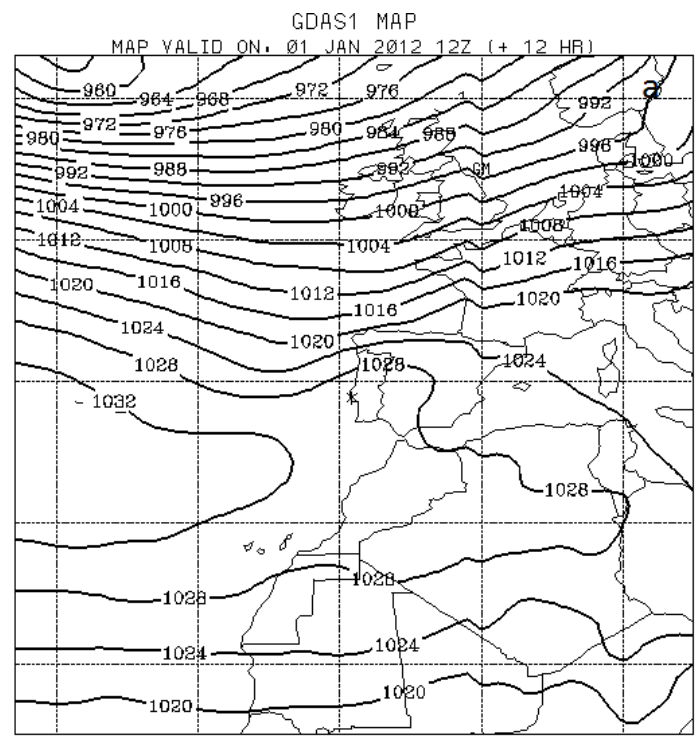

MEAN SER-LEVEL PRESSURE ( hPA )

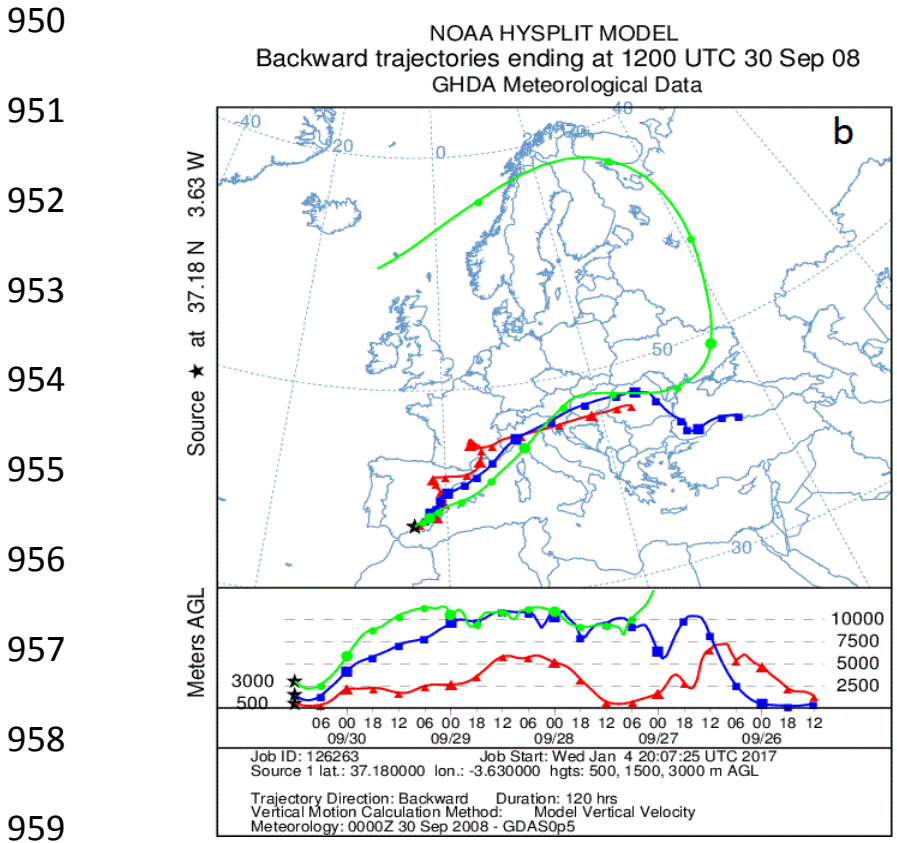

960

961

962

963 
965

966

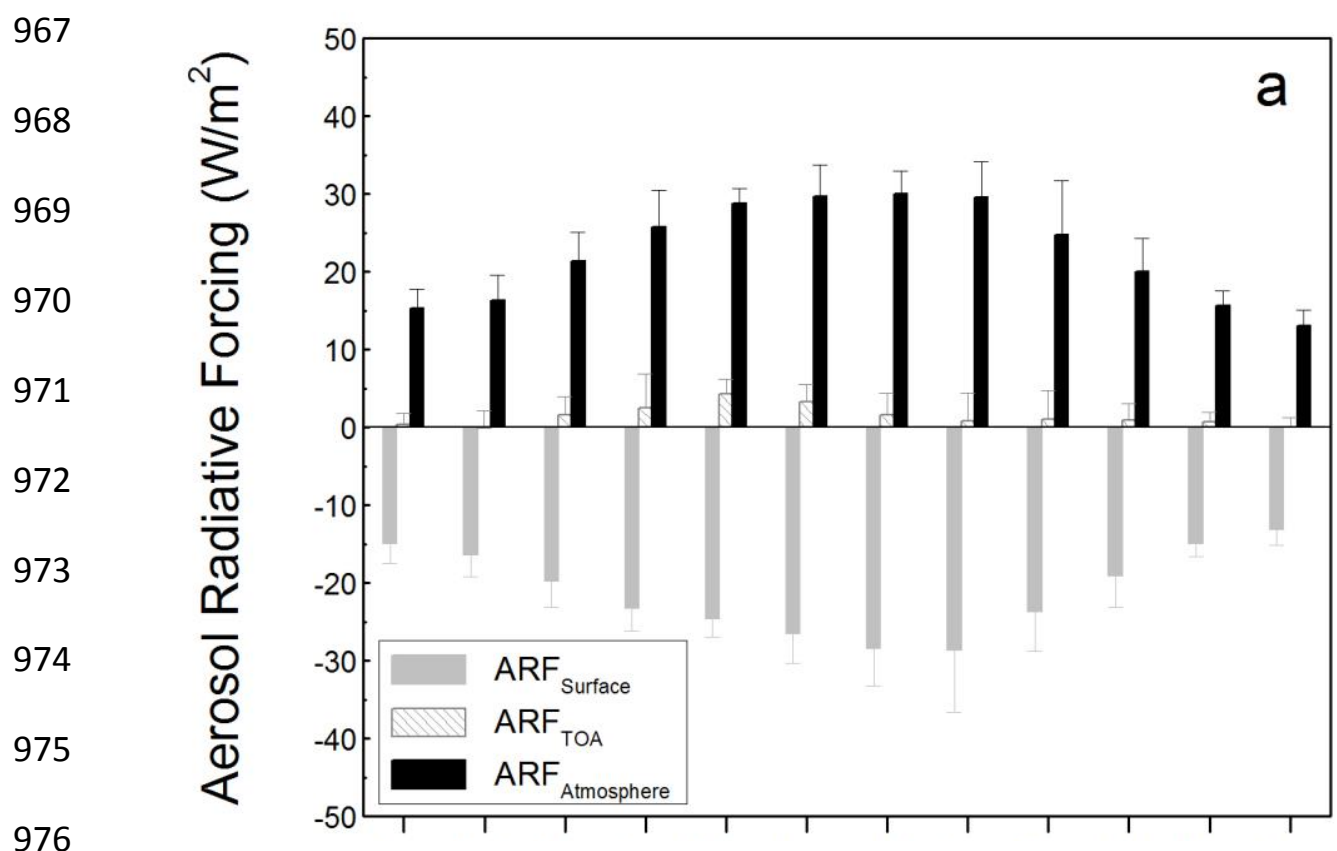

977

978

979

980

981

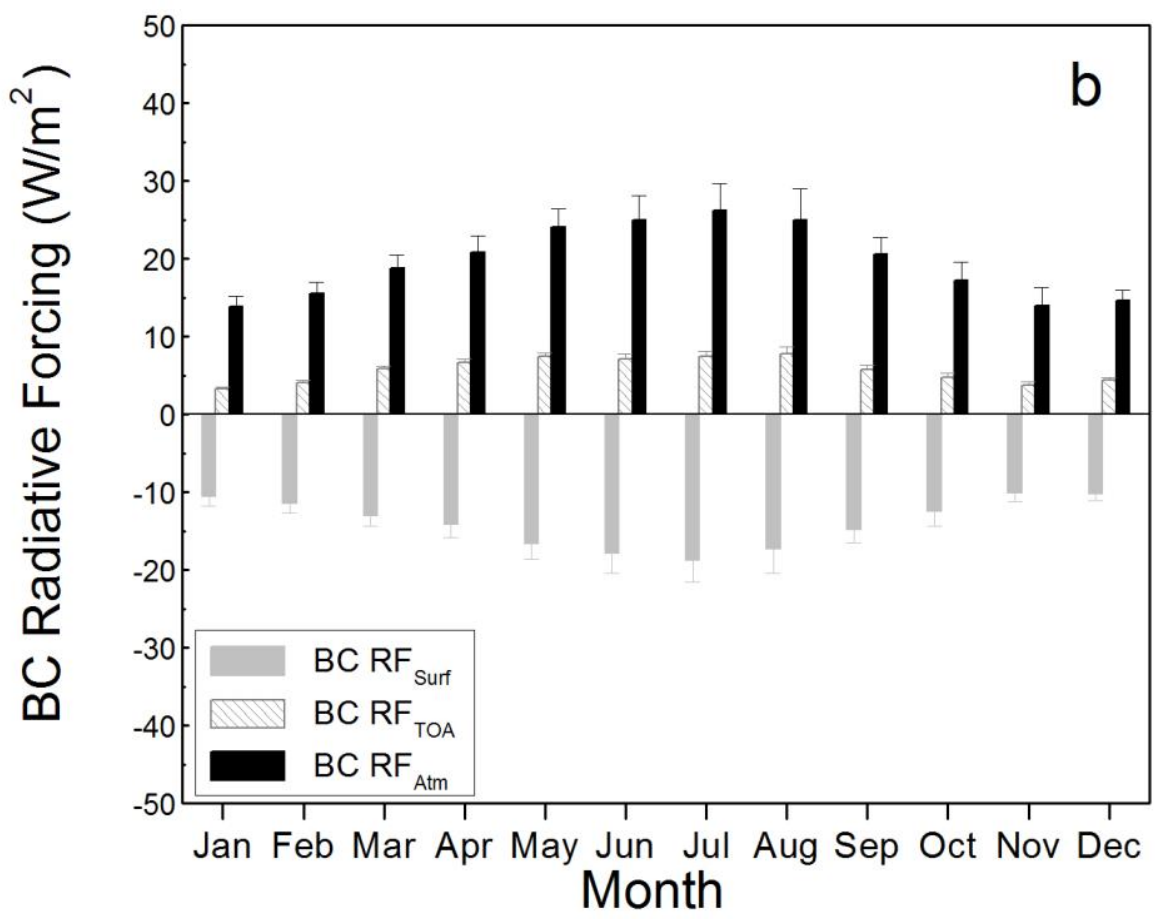

